\title{
STUDIES OF PLUTONIUM AEROSOL RESUSPENSION AT THE TIME OF THE MARALINGA CLEANUP
}

JOSEPH H. SHINN

Manuscript Date: August 2003

Lawrence Livermore National Laboratory

University of California • Livermore, CA • 94551 


\section{DISCLAIMER}

This document was prepared as an account of work sponsored by an agency of the United States Government. Neither the United States Government nor the University of California nor any of their employees, makes any warranty, express or implied, or assumes any legal liability or responsibility for the accuracy, completeness, or usefulness of any information, apparatus, product, or process disclosed, or represents that its use would not infringe privately owned rights. Reference herein to any specific commercial product, process, or service by trade name, trademark, manufacturer, or otherwise, does not necessarily constitute or imply its endorsement, recommendation, or favoring by the United States Government or the University of California. The views and opinions of authors expressed herein do not necessarily state or reflect those of the United States Government or the University of California, and shall not be used for advertising or product endorsement purposes.

This work was performed under the auspices of the U. S. Department of Energy by the University of California, Lawrence Livermore National Laboratory under Contract No. W-7405-Eng-48.

This report has been reproduced

directly from the best available copy.

Available to DOE and DOE contractors from the

Office of Scientific and Technical Information

P.O. Box 62, Oak Ridge, TN 37831

Prices available from (423) 576-8401

http://apollo.osti.gov/bridge/

Available to the public from the

National Technical Information Service

U.S. Department of Commerce

5285 Port Royal Rd.,

Springfield, VA 22161

http://www.ntis.gov/

OR

Lawrence Livermore National Laboratory

Technical Information Department's Digital Library

http://www.llnl.gov/tid/Library.html 
Introduction

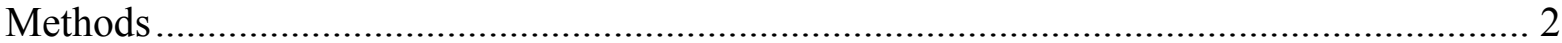

1. Measurement of the Particle Size of Suspended Dust and Suspended $\mathrm{Pu}$..................... 3

2. Measurement of the Concentration of $\mathrm{Pu}$ in Air ......................................................... 4

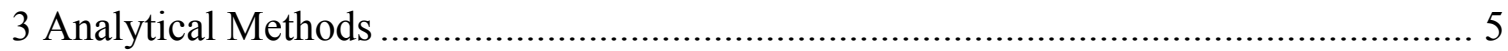

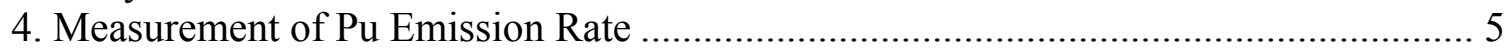

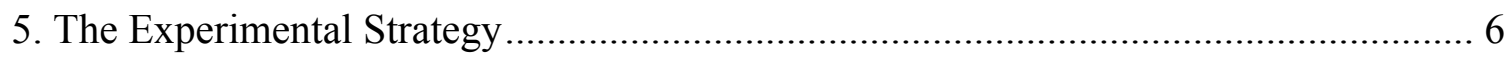

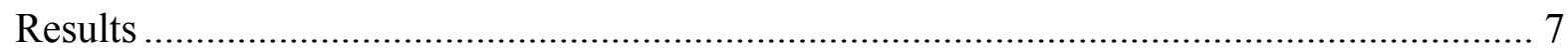

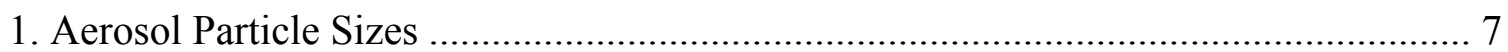

2. Comparison of $\mathrm{Pu} / \mathrm{Am}$, Resuspension Factors, and Enhancement ............................. 8

3. Variability and Uncertainty in Observed Variables ................................................... 9

4. Loss of Pu through Continued Resuspension Due to Wind Erosion............................. 19

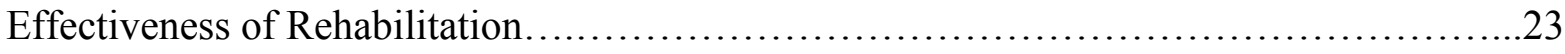

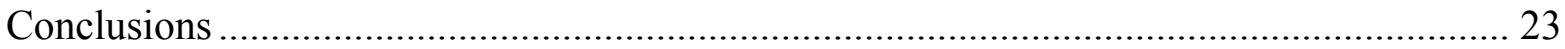

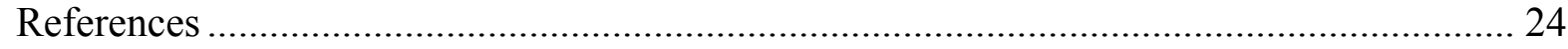

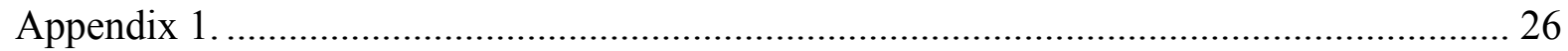

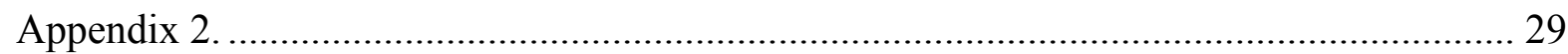

\section{List of Tables}

Table 1. Observed Characteristics of Airborne Plutonium ................................................. 8

Table 2. Dose assessment $\mathrm{Pu} / \mathrm{Am}$ Ratios and Enhancement.............................................. 8

Table 3. Resuspension Factor and TSP from Dose Assessment ......................................... 9

Table 4. Observed Variability of Plutonium Concentrations in Air ..................................... 10

Table 5. Values of Non-Dimensional Vertical Gradient, p............................................. 19

Table 6. Calculated Resuspension Rates..................................................................... 22

Table 7. Concentrations of Plutonium in Air after Rehabilitation..........................23

\section{List of Figures}

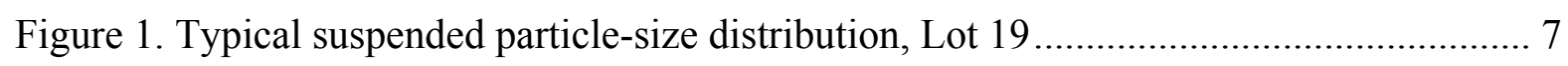

Figure 2. Pu concentrations in air at FW control site.................................................... 10 


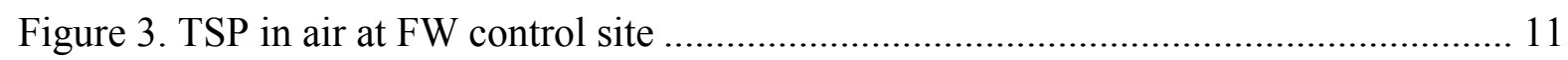

Figure 4. Pu activity in aerosols, FW control site ......................................................... 11

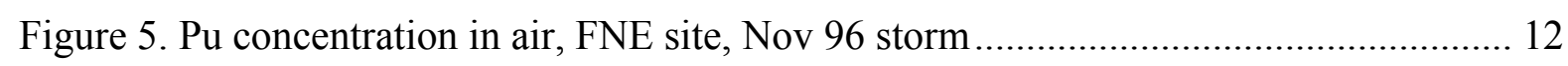

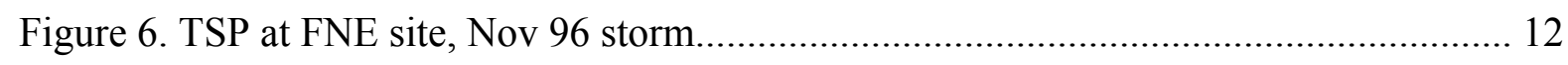

Figure 7. Pu activity in aerosols, FNE, Nov 1996, storm ............................................... 13

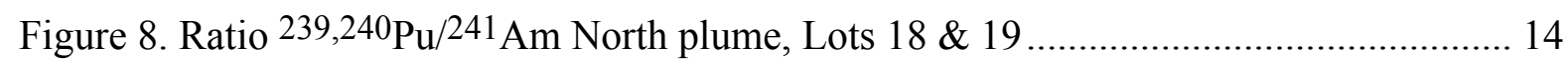

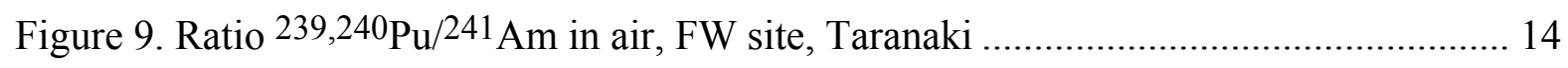

Figure 10. Concentrations of $\mathrm{Pu}$ in air, North plume Lot 18, Taranaki ............................... 15

Figure 11. Concentrations of TSP in air, North plume Lot 18, Taranaki ............................ 15

Figure 12. Pu activity, North Plume Lot 18, Taranaki....................................................... 16

Figure 13. Pu concentration in air, North plume Lot 19, Taranaki .................................... 16

Figure 14. Concentration of TSP, North plume Lot 19, Taranaki ..................................... 17

Figure 15. Pu activity in aerosols, North plume Lot 19, Taranaki...................................... 17

Figure 16. Pu concentration in air, TM-100 Lot 12, undisturbed control ............................. 18

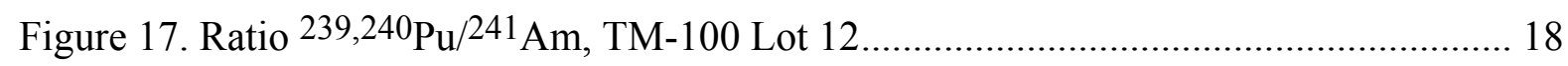

Figure 18. Vertical gradient of Pu observed at Taranaki West, FW site. ............................ 19

Figure 19. TSP profile at Taranaki West, FW site …..................................................... 20

Figure 20. Vertical gradient of $\mathrm{Pu}$ at Taranaki Northeast during storm.............................. 20

Figure 21. Vertical gradient of TSP at Taranaki Northeast during storm ........................... 21

Figure 22. Vertical profiles of Pu and TSP at TM-100 Lot 12 ........................................ 21

Figure 23. Wind speed profiles on cleaned and uncleaned plots ..................................... 22 


\title{
STUDIES OF PLUTONIUM AEROSOL RESUSPENSION AT THE TIME OF THE MARALINGA CLEANUP
}

\author{
JOSEPH H. SHINN
}

\section{INTRODUCTION}

At the former nuclear test site at Maralinga, South Australia, soil cleanup began in October 1996 with the objective to remove the potential for residual plutonium $(\mathrm{Pu})$ exposures to the public. In this case the cleanup was to restore access to the closed test site. The proposed long-term land use was primarily to be a hunting area for Pitjantjatjara (Aboriginal) people, but also presumably to be available to the public who might have an interest in the history of the site. The long-term management objective for the site was to allow casual use, but to prohibit habitation.

The goal of this study is to provide an evaluation of the Maralinga soil cleanup in terms of potential long-term public inhalation exposures to particulate $\mathrm{Pu}$, and in terms of a contribution to planning and conducting any such soil Pu-cleanup. Such cleanups might be carried out for example, on the Nevada Test Site in the United States. For Pu that has been deposited on the soil by atmospheric sources of finely divided particles, the dominant exposure pathway to humans is by inhalation. Other exposure pathways are less important because the $\mathrm{Pu}$ particles become oxidized into a nearly insoluble form, do not easily enter into the food chain, nor are they significantly transferred through the intestine to the bloodstream should $\mathrm{Pu}$ become ingested.

The purpose of this report is to provide results of the $\mathrm{Pu}$ resuspension measurements made before, during, and after the $\mathrm{Pu}$ cleanup at Maralinga, to compare these against similar measurements made elsewhere, and to interpret the results as they relate to potential longterm public exposures. (Exposures to $\mathrm{Pu}$ in dust plumes produced by mechanical disturbance during cleanup are considered short-term, unlikely to be significant for purposes of this report, and are not included).

A considerable amount of research had been conducted at Maralinga by the Australian Radiation Laboratory, now the Australian Radiation Protection and Nuclear Safety Agency (ARPANSA), prior to the cleanup (Johnston et al, 1992, Williams 1993, Johnston et al 1993, Burns et al 1994, Burns et al 1995). ARPANSA staff made major contributions to delineate the areas with $\mathrm{Pu}$ in the soil, to determine the degree of secondary soil contamination by fission products from nuclear testing, to measure $\mathrm{Pu}$ resuspension by wind erosion of the undisturbed soil, and to prepare assessments of the human health risk from residual soil $\mathrm{Pu}$.

In addition, ARPANSA supported the Maralinga cleanup to assure compliance with criteria set by an independent technical advisory committee. During the cleanup ARPANSA monitored the residual $\mathrm{Pu}$ in the soil and certified that the cleanup was complete according to the criteria. It was not the reduction in potential inhalation exposure that usually was the main driver of the cleanup, but the requirement to also remove individual hot particles and 
fragments. It is the residual microscopic particles of $\mathrm{Pu}$ in the soil, however, that have the potential for long-term human exposure.

The resuspension of respirable-size Pu particles has been studied with specialized equipment at the Nevada Test Site (Gilbert et al 1988a, Gilbert et al 1988b, Shinn et al 1989, and Shinn 1992), and at Bikini and Enewetak in the Marshall Islands (Shinn et al 1997). These efforts were in large part contributed by the Health and Ecological Assessment Division, University of California, Lawrence Livermore National Laboratory (LLNL). The study reported here is a collaboration between ARPANSA and LLNL, and was jointly supported by the United States Department of Energy, and the Commonwealth of Australia Department of Primary Industry and Energy.

\section{METHODS}

Previous experience has shown that there are site-specific variables which render uncertain the ability to predict $\mathrm{Pu}$ inhalation exposure, and that these variables should change as a direct result of mechanical disturbance, even after the short-term effects of dust plumes no longer persist. The definitions that follow are discussed in more detail in National Council on Radiation Protection and Measurements Report NCRP 129, 1999. The most common expression of $\mathrm{Pu}$ resuspension is a coefficient known as the "resuspension factor", $\mathrm{S}_{\mathrm{f}}$. It is defined as the ratio of $C$, the concentration of $\mathrm{Pu}$ in air $\left(\mathrm{Bq} \mathrm{m}^{-3}\right)$, to $D$, the surface deposition of $\mathrm{Pu}\left(\mathrm{Bq} \mathrm{m}^{-2}\right)$ :

$$
\mathrm{S}_{\mathrm{f}}=\mathrm{C} / \mathrm{D}
$$

The concentration, $C$, is dependent upon $A$, the activity in top soil $\left(\mathrm{Bq}^{-1}\right)$, upon $\mathrm{M}$, the TSP, or the amount of suspended dust expressed as total suspended particulates $\left(\mathrm{g} \mathrm{m}^{-3}\right)$, and upon $E_{f}$, the enhancement factor, which is defined as the ratio of the activity in the suspended aerosol to the activity in the top soil (regardless of the relative difference in fundamental particle sizes of the two media):

$$
\mathrm{C}=E_{f} \mathrm{~A} \mathrm{M}
$$

While the activity in the soil, $A$, should be reduced by the cleanup, the equilibrium TSP, and the enhancement of activity in the suspended dust might increase. Furthermore, the size distribution of TSP, or the size distribution of Pu activity on the TSP, could be changed to the degree that the potential inhalation and lung retention of particles would change as a result of cleanup. The lack of experience with these effects of cleanup activities required that detailed measurements be undertaken.

In addition, a consideration in the long-term potential inhalation exposure is how stable the soil surfaces might be after cleanup. The vertical flux due to wind erosion of soil-borne respirable $\mathrm{Pu}$ particles $\left(\mathrm{Bq} \mathrm{m} \mathrm{m}^{-2} \mathrm{~s}^{-1}\right)$, is constant with height, $z$, in the surface layer of the atmosphere and is given by

$$
\mathrm{Q}=\mathrm{K}\{\mathrm{dC} / \mathrm{dz}\}
$$


where the flux, $Q$, is proportional to the vertical gradient of the concentration, $d C / d z$, and the turbulent eddy diffusivity, $K$. If, for example, the vertical gradient of concentration increased drastically after cleanup it would be an indication of an unstable surface. The dependency of $K$ on surface conditions and wind speed is also important:

$$
\mathrm{K}=\mathrm{u} * \mathrm{k} \mathrm{z} / \phi
$$

Here $\phi$ is a function of atmospheric stability, and $k$ is the Karman constant (equal to 0.4). The friction velocity $u *$ is proportional to the wind speed $\left(\mathrm{u}_{2}\right.$, taken at the reference height of $2 \mathrm{~m}$ ), and the square root of a "drag" coefficient $c d$ :

$$
\mathrm{u} *=\left\{c_{d}\right\}^{1 / 2} \mathrm{u}_{2}
$$

Thus, for example, a drag coefficient made "smoother" by the soil cleanup may decrease the turbulent eddy diffusivity and also increase the effective stability of the soil surface by causing reduced dust flux due to wind erosion.

We have investigated these potential effects through a measurement program at Maralinga as follows.

\section{Measurement of the Particle Size of Suspended Dust and Suspended Pu}

An optical particle counter (Climet, model 208) has been modified for field use through the addition of an isokinetic sampling inlet fixed on a wind vane to keep the inlet faced directly into the wind. Also, a log-linear amplifier and a 128-channel, multi-channel, analyzer were used to count and aerodynamically size individual particles entering the inlet during oneminute time periods. In order to approximate isokinetic sampling, three different size inlets were used and changed for the appropriate ranges of wind speed during the one-minute sampling periods. The optical particle counter was effective over the range from 0.5 to 11 $\mu \mathrm{m}$, and was calibrated with latex spheres at $0.5 \mu \mathrm{m}, 1.1 \mu \mathrm{m}, 3.3 \mu \mathrm{m}$, and $7 \mu \mathrm{m}$ aerodynamic diameters. In addition to the optical particle counter, a small laser-nephelometer (AQ-10) was used to continuously monitor dust, and responded linearally to TSP with a DC output generated by photometrically-measured bulk-scattering of particles drawn into the optical chamber. The chamber on the AQ-10 could not be kept optically clean, however, and gradually the scattering baseline with clean air drifted with time. This baseline was determined by numerical processing of the digitally-recorded signal, and the effects of this drift removed.

Cascade impactors (Graseby-Anderson, model 65-000) were operated to collect particles for size determination of suspended mass and $\mathrm{Pu}$. These were five-stage, jet-plate type, collecting on Whatman 41 cellulose fiber media. The cascade impactors (CI) had a flow rate of

$34 \mathrm{~m}^{3} \mathrm{~h}^{-1}$ and were deployed in groups of two or four. Mass-determination was done by weighing; preceded by conditioning the fiber media at constant temperature and humidity before and after the samples were collected. Pu determination was done by radiochemical analysis of the $\mathrm{Pu}$ isotopes and americium (Am) present (discussed in part 2 below). 


\section{Measurement of the Concentration of Pu in Air}

Particles were collected by two additional methods that have increased the detectability for low levels of $\mathrm{Pu}$ particles in air. The common, "high volume" (HV) air samplers (General Metal Works) collecting on rectangular Whatman $41(8 \times 10)$ cellulose fiber filters were operated at $85 \mathrm{~m}^{3} \mathrm{~h}^{-1}$, usually in pairs. These units had no flow controllers but were monitored once or twice daily and the flow rates recorded and readjusted. There was no particle separation stage on these units (e.g. PM-10), and they were used with the tilt-roof access commonly used in TSP measurements. This type of HV air sampler has a long history of use for Pu measurements in air and served as a "reference method". The cellulose fiber filter media was preferred for dissolution or ashing prior to Pu determination, and Whatman 41 has a high collection efficiency for solid particles when the flow rates are large enough to sustain a face velocity over $0.25 \mathrm{~m} \mathrm{~s}^{-1}$. Mass was determined for TSP in the same manner as for cascade impactors. Miniature HV systems were also utilized to measure the vertical gradient of $\mathrm{Pu}$ and TSP. Four of these units were run from a single $\mathrm{HV}$ motor and they were placed in a vertical array (VAS) at $0.25,0.5,1$, and $2 \mathrm{~m}$ heights. Flow rates were periodically checked with a calibrated venturi unit.

"Ultra high volume" (UHV) air samplers were used to assure detectability of extremely low levels of $\mathrm{Pu}$ in air. Two of these air samplers were designed and constructed by LLNL, to collect particles at a rate from $800-1300 \mathrm{~m}^{3} \mathrm{~h}^{-1}$ onto a one- $\mathrm{m}^{2}$, cellulose fiber filter cut from Whatman 41 rolls. The UHV blowers were high-pressure centrifugal fans driven by 5-hp electric motors. The filter beds were stainless steel cylindrical screens with a vertical axis (effective screen height $0.62 \mathrm{~m}$ by $1.74 \mathrm{~m}$ circumference with an $0.12-\mathrm{m}$ inefficient overlap) and three bands to hold the filters in place. Flow rates were monitored through manometers on pitot tubes mounted into the $0.2-\mathrm{m}$ diameter pipe sections used to deflect fan exhaust. Calibration of this flow monitor was performed against a $1700 \mathrm{~m}^{3} \mathrm{~h}^{-1}$ Merriam laminar flow element (LFE) on the loaded intake of the UHV. Calibration equations of LFE versus the flow monitors for filters under load were linear, but discharges at the exhaust were increased over intake flow due to small air leaks into the fan shroud, so the equations had a nonzero offset and a non-unity slope. The UHV filters were ashed, and ash weights were corrected by subtracting ash weights from blank filters to determine residual TSP. The UHV filters had sufficient particles collected in $48 \mathrm{~h}$ so that gamma spectroscopy of the compressed filters could be used to quantify the weak gamma peak of ${ }^{241} \mathrm{Am}$ at $60 \mathrm{keV}$. These measurements of ${ }^{241} \mathrm{Am}$ enabled rapid and economical estimation of $\mathrm{Pu}$ in air via the known $\mathrm{Pu} / \mathrm{Am}$ ratio (discussed below), but also allowed the radiochemists to be prepared for the particular level of $\mathrm{Pu}$ that might be expected in subsequent analysis of UHV and other filters. After gamma spectroscopy, the UHV filters were analyzed by radiochemistry. At the conclusion of the rehabilitation at Maralinga, the UHV units were used to measure extremely low $\mathrm{Pu}$ concentrations in air, which demanded the use of accelerator mass spectroscopy methods (McAninch et al, 1999) to detect Pu on these special filters.

The $\mathrm{Pu} / \mathrm{Am}$ ratio as observed is defined as the ratio of $239,240 \mathrm{Pu}$ to ${ }^{241} \mathrm{Am}$, and had been earlier determined in the soil by ARPANSA (Burns et al, 1994). The technical advisory group considered these $\mathrm{Pu} / \mathrm{Am}$ ratios when the cleanup criteria were adopted. Because of the ease of measurement of ${ }^{241} \mathrm{Am}$ in the soil in situ, the Maralinga cleanup criteria were written to use that measurement, exclusively, to certify that cleanup had been complete. ARPANSA used both a mobile unit for surface gamma spectroscopy with a high purity germanium diode detector on a telescoping boom, and a small truck with four sodium iodide detectors mounted 
on the bumper for ${ }^{241} \mathrm{Am}(60 \mathrm{keV})$ measurement. Both of these vehicles had geographical positioning systems for accurate mapping.

In addition, all air samples collected by us were analyzed for ${ }^{239,240} \mathrm{Pu},{ }^{238} \mathrm{Pu}$, and ${ }^{241} \mathrm{Am}$ by radiochemistry, and the $\mathrm{Pu} / \mathrm{Am}$ ratio $\left(239,240 \mathrm{Pu} /{ }^{241} \mathrm{Am}\right)$ determined. Thus measurements of ${ }^{241} \mathrm{Am}$ either on air samples or on bare soil by gamma spectroscopy could be used to estimate $\mathrm{Pu}$ via the $\mathrm{Pu} / \mathrm{Am}$ ratio.

In both the ARPANSA and LLNL laboratories, gamma spectroscopy for ${ }^{241} \mathrm{Am}$ was applied to air filters compressed into standard geometry containers that had been routinely used, and these samples were compared against reference ${ }^{241} \mathrm{Am}$ standards of the same geometry. Six of the Maralinga air samples were split and interchanged between ARPANSA and LLNL to compare ${ }^{241}$ Am gamma measurement quality.

$\mathrm{Pu}$ radiochemistry was performed the same on all air samples (UHV, HV, cascade impactors, and vertical array samplers). After weights of collected mass were determined, and estimates made of the $\mathrm{Pu}$ levels based on soil activity levels and $\mathrm{Pu} / \mathrm{Am}$ ratio, the samples were submitted for analysis.

\section{Analytical Methods}

For transuranic isotopes, ${ }^{239,240} \mathrm{Pu}$ and ${ }^{241} \mathrm{Am}$, special chemical methods were required. On filter media, the isotopes were recovered by acid total-dissolution, ion-exchange separation, and electrodeposition, and measured by alpha spectrometry using internal chemical yield tracers of ${ }^{242} \mathrm{Pu}$ and ${ }^{243} \mathrm{Am}$. Details of the protocol are provided in Wong et al, 1995. Quality assurance was carried out through adherence to established protocols, (Kehl et al, 1995) and by use of quality control procedures (blank filters, control filters-carried to the site and back without use, and standards). Analytical accuracy has been maintained among these methods for the analysis of $\mathrm{Pu}$ (from atmospheric fallout) in shallow or deep marine sediments or in soil and sediment samples collected from the Pacific Test Sites at Bikini and Enewetak Atolls (close-in fallout). The method has also been used in the analysis of Pu in NIST Radioactivity Standard Reference Materials (Rocky Flats Soil and Columbia River Sediment) and in IAEA interlaboratory comparison samples. The alpha chemistry precision of the air filters was better than $0.005 \mathrm{~Bq} /$ sample for ${ }^{239,240} \mathrm{Pu}$ and ${ }^{241} \mathrm{Am}$, and the minimum detectability was $0.005 \mathrm{~Bq} /$ sample.

\section{Measurement of Pu Emission Rate}

Measurements of the vertical gradients of TSP and C were accomplished by a "vertical array" of air samplers at four heights (they varied only slightly from the heights $0.25 \mathrm{~m}, 0.5 \mathrm{~m}, 1 \mathrm{~m}$, and $2 \mathrm{~m}$ ). There were two sets of four each, inverted filter holders with Whatman 41 filters $0.09-\mathrm{m}$ diameter, and a flow rate of 10 to $20 \mathrm{~m}^{3} \mathrm{~h}^{-1}$. These were deployed either at separate locations or as duplicates, and air flow-rates were monitored once or twice daily by means of a calibrated venturi device. These smaller filters were handled in the same manner as HV or cascade impactor filters. In order to facilitate calculation of the gradients, a nondimensional form of the gradient was used (Anspaugh et al, 1975):

$$
p=\{\mathrm{z} / \mathrm{c}\} \mathrm{dC} / \mathrm{dz}
$$


From past experience, the value of $p$ tended to remain constant for a given experiment, and was obtained by least-squares, linear fit to the $\log C, \log \mathrm{z}$ transformed variables. Values of $p$ have been obtained as a measure of soil surface stability at many other sites where resuspension of $\mathrm{Pu}$ has been observed, and was determined for TSP in the same manner. To calculate the flux, $Q$, the mean value of $C$ (or TSP) was used at the height of $1.2 \mathrm{~m}$, and the diffusivity, $K$, was determined at $2 \mathrm{~m}$ height and the value adjusted for height.

To obtain values of the diffusivity, $K$, an automatic meteorological station (Campbell Scientific Inc, model CR-10) was installed, and meteorological data were recorded in tenminute averages for the duration of the air-sampling period. The primary method of determining the diffusivity, $K$, was by measuring the sensible heat flux and then dividing the measured eddy correlation by the vertical temperature gradient over the same period. Sensible heat flux was measured by the eddy correlation of vertical turbulence, $w$, and temperature fluctuation, $T^{\prime}$, using a vertical, one-dimensional, sonic anemometer (Campbell Scientific Inc, model CA-27) with a fast response thermocouple,. This is a direct method, and assumes only that the diffusivity for Pu and TSP is the same as that of diffusivity for heat:

$$
\mathrm{K}=-<\mathrm{w}^{\prime} \mathrm{T}^{\prime}>/\{\mathrm{dT} / \mathrm{dz}\}
$$

The automatic meteorological station recorded the wind speed, wind direction, and as a quality check, recorded sensors that measure the surface energy budget by the Bowen ratio technique, and determine the sensible heat flux indirectly. This same station also recorded the TSP monitoring data from the AQ-10. Ten-minute summaries of all signals were recorded and downloaded daily into a laptop computer in the field.

\section{The Experimental Strategy}

A measurement strategy for the resuspension measurements at Maralinga was to compare two sites at a time. (A map of Maralinga as well as the detailed layout of cleaned plots is shown in Appendix 1.) Each site was chosen to be representative of a particular condition. In November 1996, a control site was established at a location known as FW, on the west deposition plume at Taranaki. This site was unique in that it had a non-hazardous but measurable amount of $\mathrm{Pu}$ in the soil. It had been the location of earlier resuspension measurements by ARPANSA, and it had never been disturbed by the ploughing operations in the attempts at soil stabilization by the British during Operation Brumby in 1967. During the period in November, 1996, a cleaned plot (Lot 37) in the northeast plume at Taranaki, representing a location that had been cleaned but not yet stabilized, was also studied. This site was also near the FNE location where resuspension measurements were made by ARPANSA prior to the cleanup. In March 1997, a cleaned plot (Lot 19) in the north plume at Taranaki was investigated, representing another recently cleaned but not yet stabilized location. This was also near the FN site where ARPANSA had measured resuspension prior to the cleanup. At the same time in March 1997, a site was studied to the north just outside of Lot 18, the north end of the cleaned north plume at Taranaki, where soil had blown out of Lot 18 during a dust storm in November 1996. This site represented a possible recontamination area, with unstabilized, unconsolidated, recent deposits. Then, in May, 1997, the UHVs were moved to a situation similar to the latter case. This was a simpler study (only UHVs) and compared the northernmost, cleaned lot in the northwest plume at Taranaki (Lot 1) to a site beyond the north end of the same plot. Here again, soil had blown out of Lot 1 during a dust 
storm, and could possibly represent a recontamination area with unstabilized and unconsolidated deposits.

In October 1997, the Taranaki surface cleanup had been completed, so that resuspension studies moved to the TM-100 cleanup location, where the type of contaminating-Pu dispersal was known to be different from that at Taranaki. A site was chosen in the middle of a cleaned area representative of the cleaned north plume (Lot 12) at TM-100. A second site was chosen at $\mathrm{TM}$ on the west side of Lot 12 on an uncleaned area with a non-hazardous, but measurable amount of $\mathrm{Pu}$. This uncleaned area represented an undisturbed control site for TM-100 and was surveyed for ${ }^{241}$ Am by ARPANSA.

Rehabilitation of cleaned areas were investigated during April and May 2000, when the UHV units were operated consecutively at Taranaki, TM-100, and Wewak sites to determine the Pu concentrations in air as a measure of rehabilitation success. As a control, $6 \mathrm{HV}$ units were operated simultaneously and continuously at Maralinga Village, near the building containing the whole body counter. Another control was the GARD air sampling system operated at ARPANSA in Melbourne during the same time period.

\section{RESULTS}

\section{Aerosol Particle Sizes}

Particle size studies that were conducted with the optical particle counter (on Lot 19 and the recontaminated site north of Lot 18 in Taranaki North plume) showed that there was considerable detail in the TSP distribution with particle size (aerodynamic diameter). In the particle diameter range of 0.5 to $10 \mu \mathrm{m}$ it was possible to detect at least 2 minor modes and one major mode; for example, see Fig 1. But the dominant mode was near $3.9 \mu \mathrm{m}$ with a minor mode between 5 and $6 \mu \mathrm{m}$ and a minor mode between $8 \mu \mathrm{m}$ and $10 \mu \mathrm{m}$. Interpretation of minor-mode data and how they vary was undertaken in detail by Bertoldo 1998, See Appendix 2.

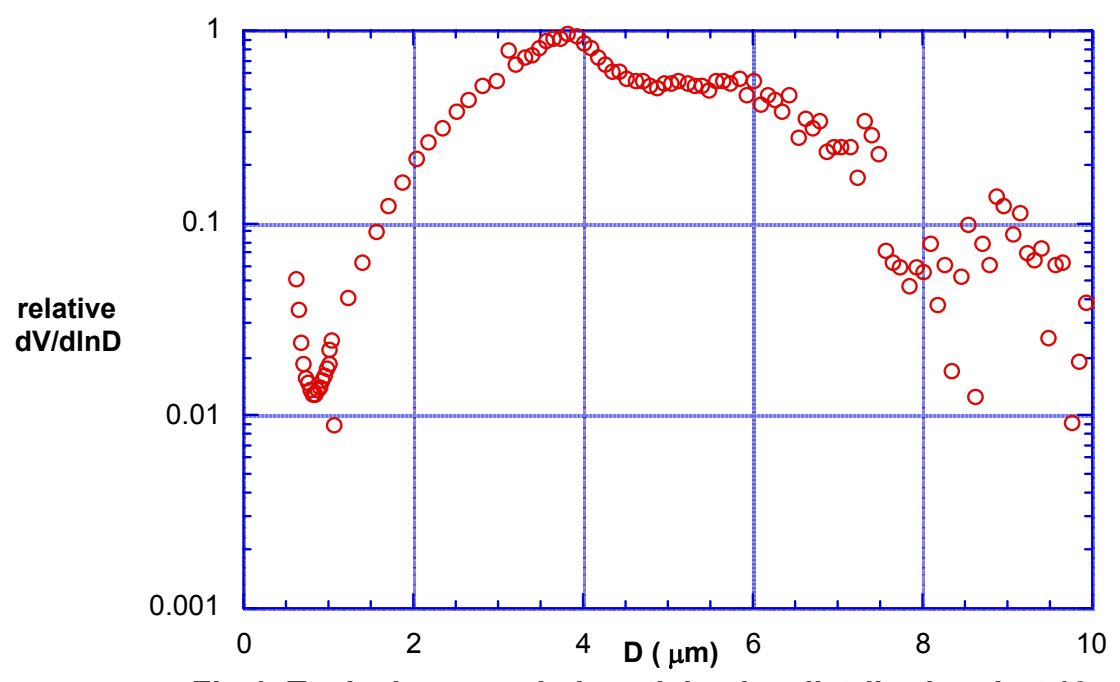

Fig 1. Typical suspended particle-size distribution, Lot 19 
The cascade impactor data could not distinguish the minor modes at these sites, but they showed nevertheless that the mass median aerodynamic diameter of TSP (MMAD) was $3.0 \mu \mathrm{m}$ on Lot 19 and $3.2 \mu \mathrm{m}$ on Lot 18 . The MMAD on the historically unploughed and uncleaned FW control site was $4.0 \mu \mathrm{m}$ while the activity median aerodynamic diameter for $\mathrm{Pu}$ (AMAD) was $4.7 \mu \mathrm{m}$. All of these cascade impactor derived median values tend to agree with the dominant mode found by the optical particle counter. See Table 1. The particle sizes fall for the majority in the middle of the respirable size range, $1-10 \mu \mathrm{m}$.

\section{TABLE 1. OBSERVED CHARACTERISTICS OF AIRBORNE PLUTONIUM}

\begin{tabular}{ccccccc}
\hline Site & $\begin{array}{c}\text { Mean Air } \\
\text { Activity } \\
(\mathrm{Bq} / \mathrm{g})\end{array}$ & $\begin{array}{c}\text { AMAD* } \\
(\mu \mathrm{m})\end{array}$ & $\begin{array}{c}\text { MMAD** } \\
(\mu \mathrm{m})\end{array}$ & Easting & Northing & Comments \\
\hline Taranaki West & 1 & 4.7 & 4 & & & $\begin{array}{c}\text { FW site, } \\
\text { undisturbed } \\
\text { Taranaki North } \\
\# 19\end{array}$ \\
$\begin{array}{c}\text { Taranaki North } \\
\# 18\end{array}$ & 2.2 & 2.8 & 3 & 750207 & 6691078 & Cleaned site \\
$\begin{array}{c}\text { Taranaki Northeast } \\
\text { TM-100 }\end{array}$ & 2.3 & 6.9 & 3.2 & 750145 & 6691313 & $\begin{array}{c}\text { Uncleaned, } \\
\text { recontaminated } \\
\text { Cleaned site }\end{array}$ \\
\hline
\end{tabular}

* Activity Median Aerodynamic Diameter from high volume cascade impactors.

** Mass Median Aerodynamic Diameter from high volume cascade impactors.

\section{Comparison of Pu/Am, Resuspension Factors, and Enhancement}

We found good agreement between the $\mathrm{Pu} / \mathrm{Am}$ ratios observed by LLNL during the 1996-1997 investigations and those recommended by Williams, 1993, for Taranaki sites in the IAEA dose assessment report. These measurements were a little different, in that the $\mathrm{Pu} / \mathrm{Am}$ ratio from LLNL alpha spectroscopy was ${ }^{239,240} \mathrm{Pu}$ to ${ }^{241} \mathrm{Am}$ while Burns et al, 1994, were able to separate ${ }^{239} \mathrm{Pu}$ and ${ }^{240} \mathrm{Pu}$, however, the results should be fairly comparable. The ratio of ${ }^{239} \mathrm{Pu}$ to ${ }^{241} \mathrm{Am}$ from Williams, 1993, is the $\mathrm{Pu} / \mathrm{Am}$ reference value shown in Table 2. The observed standard deviations from the many samples in 1996-1997 are shown (sd in Table 2).

We found a much lower $\mathrm{Pu} / \mathrm{Am}$ ratio for TM-100, however, and a very low enhancement factor (last row in Table 2). It could well be that our observations were made on a site that was not characteristic of the whole TM-100. In any case the dose assessment would have an added safety factor here.

TABLE 2. DOSE ASSESSMENT Pu/Am RATIOS AND ENHANCEMENT: COMPARISON TO OBSERVED VALUES

\begin{tabular}{lcccc}
\hline \multicolumn{1}{c}{ Site } & Reference* Pu/Am & Observed** Pu/Am & $\begin{array}{c}\text { Reference* } \\
\text { Enhancement }\end{array}$ & $\begin{array}{c}\text { Observed } \\
\text { Enhancement } E_{f}\end{array}$ \\
\hline Taranaki West & 8 & $6(\mathrm{sd} \mathrm{2.5)}$ & 6 & 2 \\
Taranaki North & 8 & $10(\mathrm{sd} \mathrm{3.7})$ & 6 & 2 \\
Taranaki Northeast & 9 & $6.4(\mathrm{sd} \mathrm{0.7)}$ & 6 & 6 (during storm) \\
TM-100 & 20 & $3(\mathrm{sd} \mathrm{1.7})$ & 4 & 0.0003 \\
\hline
\end{tabular}

* G.A. Williams, IAEA-TECDOC-755, 1993 
**Reference $\mathrm{Pu}$ is $\mathrm{Pu}-239$, but Observed $\mathrm{Pu}$ includes both $\mathrm{Pu}-239$ and $\mathrm{Pu}-240 . \mathrm{Pu}-239$ was the dominant isotope in this mix, typically greater than $80 \%$. Am is Am-241, a daughter isotope of Pu. Variability is shown by standard deviation, sd.

The resuspension factors obtained during the period 1996-1997, combining all HV, UHV, and CI data offer useful comparisons to data from Johnston et al (1993)-see Table 3. For FW site at Taranaki West, which was the undisturbed control plot for Taranaki, we obtain nearly the same results. But for sites that were cleaned in the Taranaki North and Northeast plumes the resuspension factor increased by an order of magnitude as a result of disturbance and removal of topsoil, as expected. During a dust storm in November 1996, the resuspension factor was temporarily increased, most likely a result from advected $\mathrm{Pu}$ aerosols from beyond the plot boundary. At TM-100 the cleaned site had a resuspension factor increased by a factor of more than 2 compared to the undisturbed control plot. The mean mass loading of the atmosphere, TSP, had similar values observed in 1996-1997 to those reported by Johnston et al, 1993, which had a range $14-41 \mu \mathrm{g} / \mathrm{m}^{3}$. From comparison to the reference values of resuspension factor and mean TSP that were recommended in the IAEA dose report (see the first row of Table 3), it is clear that the observations show how conservative the assumption was for dose assessment purposes.

TABLE 3. RESUSPENSION FACTOR AND TSP FROM DOSE ASSESSMENT: COMPARISON TO OBSERVED VALUES

\begin{tabular}{|c|c|c|c|c|c|}
\hline Site & $\begin{array}{c}\text { Resuspension } \\
\text { Factor }(1 / \mathrm{m}) \\
1993 * * *\end{array}$ & $\begin{array}{c}\text { Resuspension } \\
\text { Factor }(1 / \mathrm{m}) \\
1996-1997\end{array}$ & $\begin{array}{c}\text { Mean TSP } \\
\left(\mu \mathrm{g} / \mathrm{m}^{3}\right) \\
1996-1997\end{array}$ & TSP Variability** & Comment \\
\hline $\begin{array}{l}\text { Reference } \\
\text { Values* }\end{array}$ & $6.00 \times 10^{-08}$ & & 1000 & (not applicable) & $\begin{array}{l}\text { Conservative } \\
\text { estimate }\end{array}$ \\
\hline Taranaki West & $3.3 \times 10^{-10}$ & $3.0 \times 10^{-10}$ & 14 & GM 13, GSD 1.6 & $\begin{array}{l}\text { Undisturbed } \\
\text { control }\end{array}$ \\
\hline $\begin{array}{c}\text { Taranaki North, } \\
\text { \#19 }\end{array}$ & $6.0 \times 10^{-11}$ & $4.0 \times 10^{-09}$ & 28 & GM 23, GSD 1.9 & Cleaned site \\
\hline $\begin{array}{c}\text { Taranaki North, } \\
\# 18\end{array}$ & $6.0 \times 10^{-11}$ & $1.3 \times 10^{-09}$ & 47 & GM 36, GSD 2.1 & $\begin{array}{l}\text { Undisturbed, } \\
\text { recontaminated }\end{array}$ \\
\hline $\begin{array}{l}\text { Taranaki } \\
\text { Northeast }\end{array}$ & $1.2 \times 10^{-10}$ & $1.4 \times 10^{-09}$ & 14 & GM 13, GSD 1.6 & cleaned site \\
\hline $\begin{array}{c}\text { Taranaki } \\
\text { Northeast, (storm) }\end{array}$ & $1.2 \times 10^{-10}$ & $5.9 \times 10^{-07}$ & 967 & GM 903, GSD 1.5 & 24-hour dust storm \\
\hline $\begin{array}{c}\text { TM-100 } \\
\text { undisturbed }\end{array}$ & UNKNOWN & $2.8 \times 10^{-11}$ & 21 & SD 9 & $\begin{array}{l}\text { Undisturbed } \\
\text { control }\end{array}$ \\
\hline $\begin{array}{l}\text { TM-100 cleaned } \\
\text { site }\end{array}$ & UNKNOWN & $6.6 \times 10^{-11}$ & 15 & SD 3 & Cleaned site \\
\hline
\end{tabular}

* G. A. Williams, IAEA-TECDOC-755, 1993

**Variability is shown by standard deviation, SD, or geometric standard deviation, GSD, of a log normal distribution. GM is the geometric mean. This is combined data of all HV, UHV, and CI.

*** Johnston et al, J. Environ. Radioactiv.20,1993, 117-131.

\section{Variability and Uncertainty in Observed Variables}

$\mathrm{Pu}$ activity in the air and the resulting air concentrations vary in time and space. A complete discussion of variability of the terms in the equations for inhalation exposure (Eqns 1 and 2 in 
Methods section) is given in the report NCRP 129, 1999. During any particular observation period, the LLNL sampler systems showed variation as well. It is not possible to separate sources of variability since observational problems combine with environmental factors to produce the total variability. A summary of the variability observed during 1996-1997 is presented in Table 4. In most cases, the concentrations of $\mathrm{Pu}$ in air, and TSP in air approximately follow a log normal distribution. The results are that the mean is greater than the median, and deviation is expressed as the geometric standard deviation, or GSD. The properties of a log normal distribution are that the cumulative $84^{\text {th }}$ percentile is a multiple of the median times the GSD, and the cumulative $16^{\text {th }}$ percentile is given by the median divided by the GSD.

TABLE 4. OBSERVED VARIABILITY OF PLUTONIUM CONCENTRATIONS IN AIR

\begin{tabular}{ccccc}
\hline Site & $\begin{array}{c}\text { Mean } \\
\left(\mu \mathrm{Bq} / \mathrm{m}^{3}\right)\end{array}$ & $\begin{array}{c}\text { Median } \\
\left(\mu \mathrm{Bq} / \mathrm{m}^{3}\right)\end{array}$ & Variability* & Comments \\
\hline Taranaki West & 22 & 13 & GSD 3.5 & Undisturbed control site \\
Taranaki North \#19 & 51 & 52 & GSD 2.7 & Cleaned site \\
Taranaki North \#18 & 77 & 56 & GSD 2.5 & Uncleaned, recontaminated \\
Taranaki Northeast (normal) & 7 & 7 & SD 3.3 & Cleaned site \\
Taranaki Northeast (storm) & 3212 & 2418 & GSD 2.3 & Cleaned site, 24-h storm \\
TM-100 & 0.35 & 0.31 & GSD 1.62 & Undisturbed control site \\
\hline
\end{tabular}

* Variability is shown by standard deviation, SD, or geometric standard deviation, GSD, of a log normal distribution.

Occasionally, however, a normal distribution or some unknown distribution might apply. In these cases the variation is expressed as a standard deviation, SD.

At the undisturbed control plot on the Taranaki West plume, FW site, the concentration $\mathrm{C}$ of $\mathrm{Pu}$, concentration $\mathrm{M}$ of $T S P$, and air activity, $E_{f} \mathrm{~A}$ of Eq 2, were all $\log$ normally distributed, and are shown in Figs 2, 3, and 4.

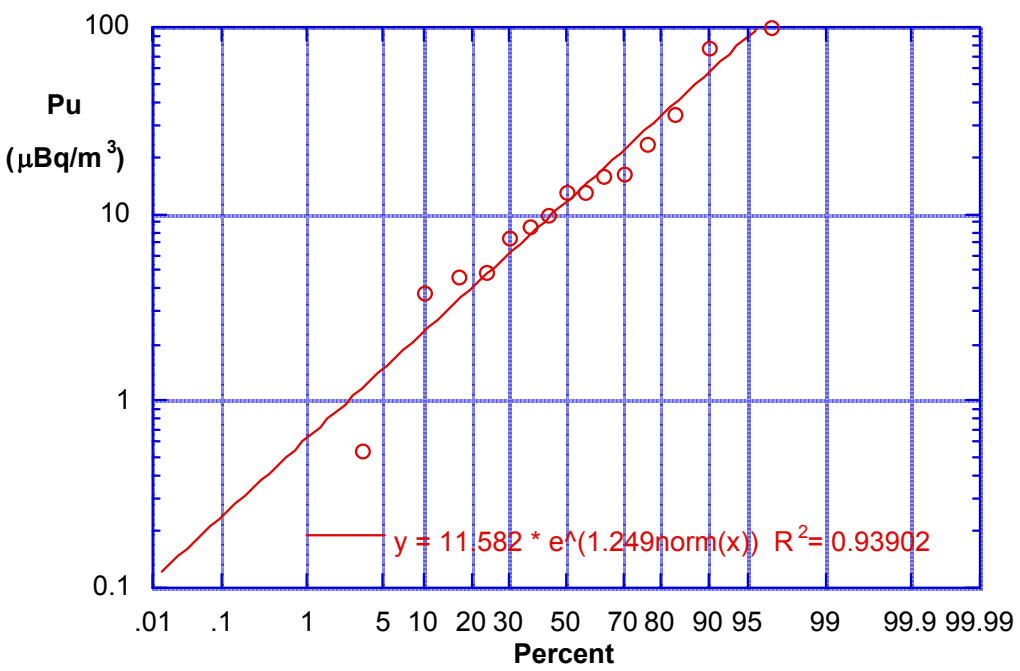

Fig 2. Pu concentrations in air at FW control site 


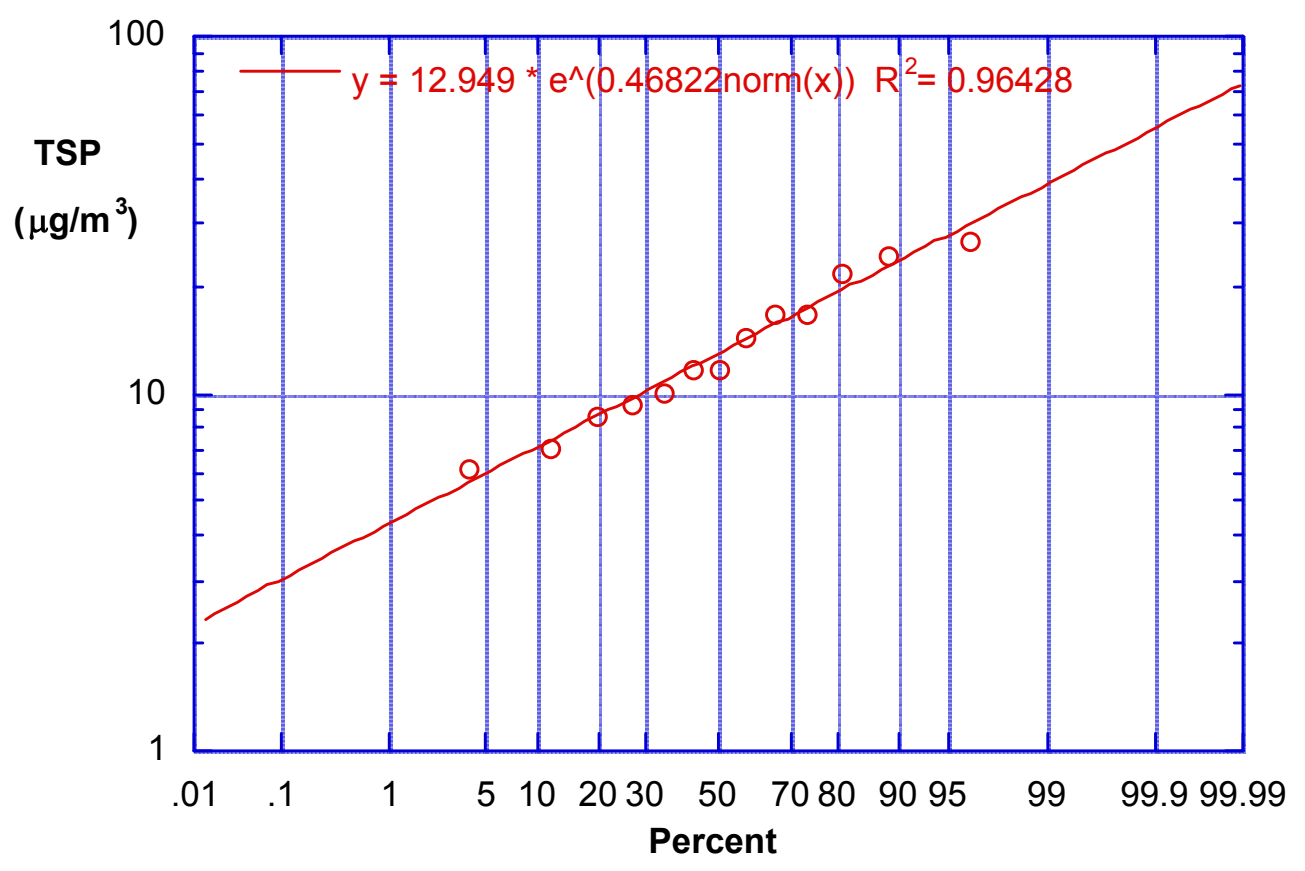

Fig 3. TSP in air at FW control site

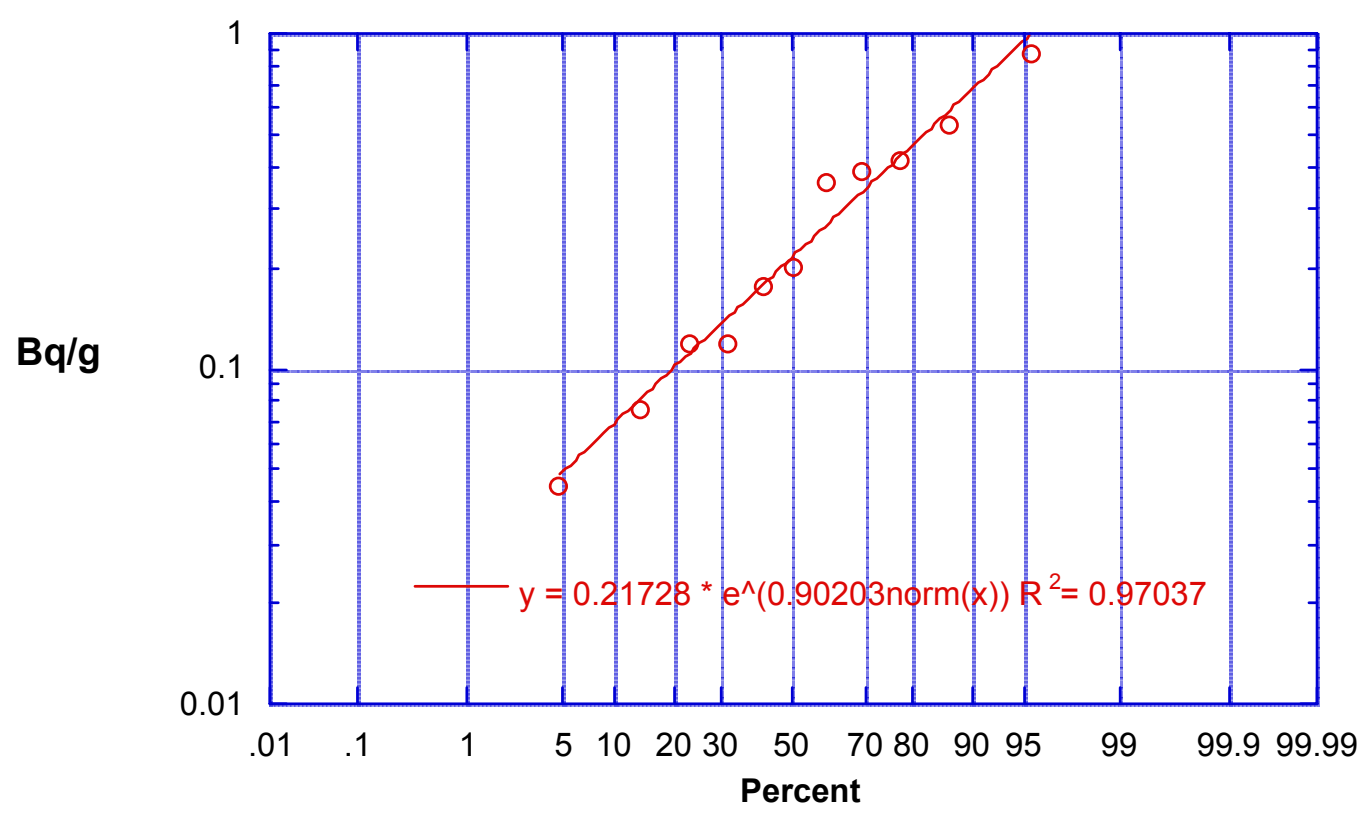

Fig 4. Pu activity in aerosols, FW control site

Log normal distributions were observed even in the case of an unusual dust storm, such as occurred in November 1996 on the Taranaki Northeast plume after it had been disturbed in preparation for soil removal- (see distributions of C, M, and $E_{f} \mathrm{~A}$ in Figs 5, 6, and 7). 


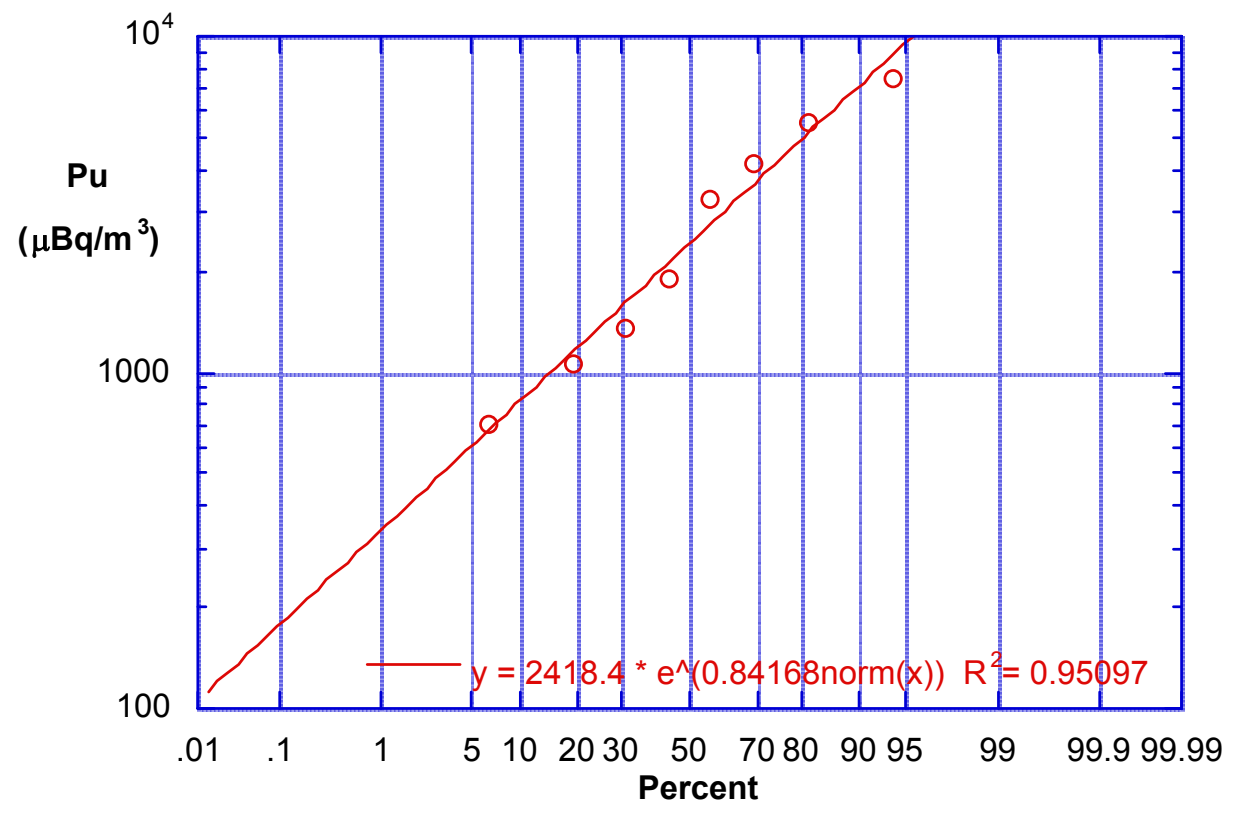

Fig 5. Pu concentration in air, FNE site, Nov 96 storm.

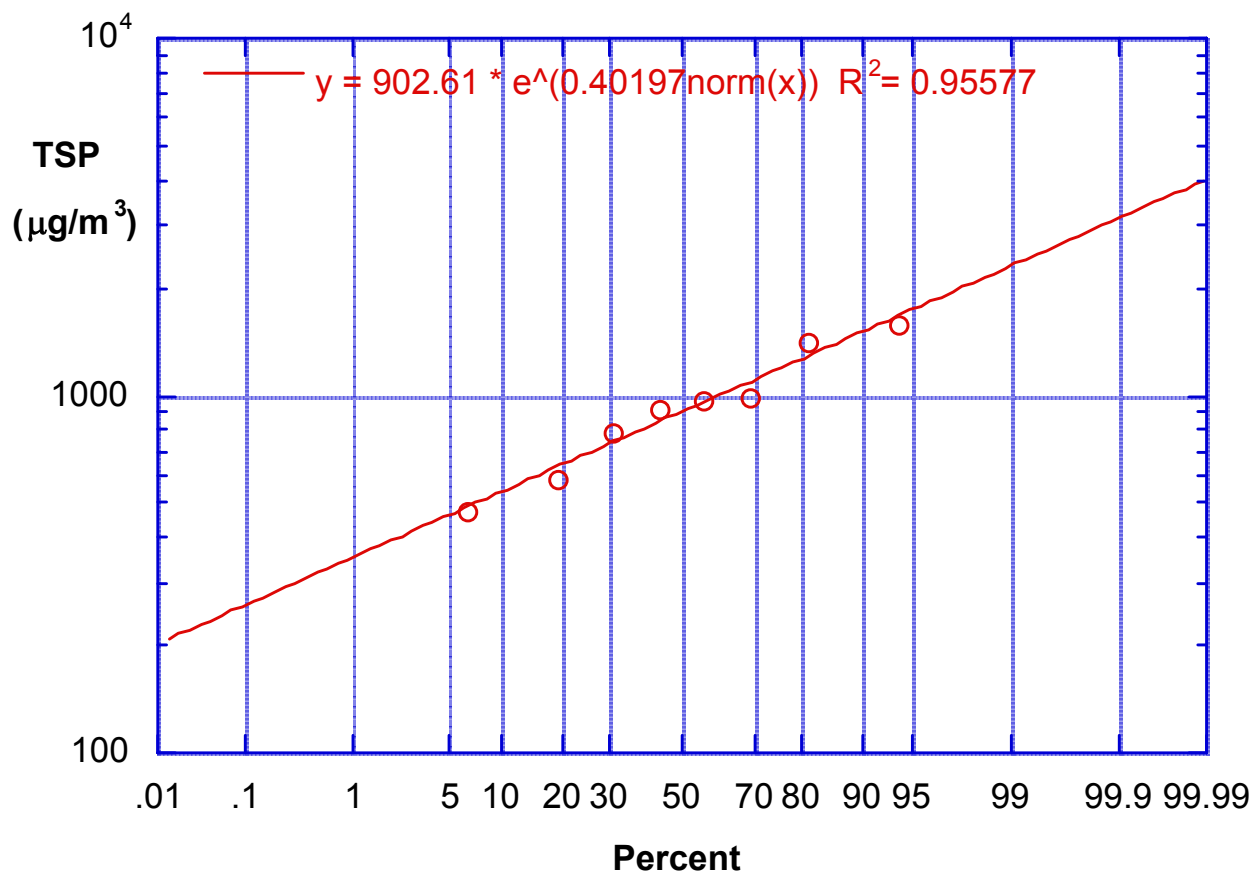

Fig 6. TSP at FNE site, Nov 96 storm 


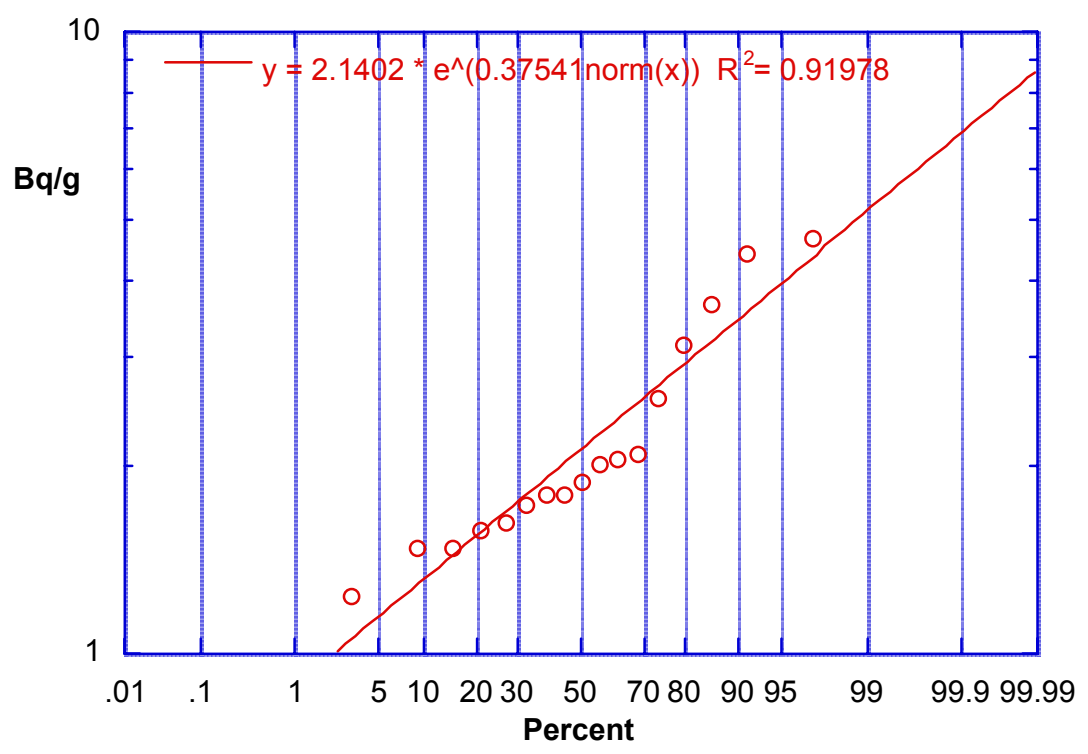

Fig 7. Pu activity in aerosols, FNE, Nov 1996, storm

The dust storm caused the mean values to be elevated, but the characteristics of the log normal distribution remained the same. For detailed risk assessments, the variability would be useful to determine the propagation of variability to the estimate of exposure from combined variables, and the uncertainty could be modeled in a Monte-Carlo sense. For bounding-case dose assessments, as in the case of Maralinga where conservative values are applied the combined variability is not always used.

Another source of variability is in the $\mathrm{Pu} / \mathrm{Am}$ ratios. (In our observations, we did not calculate $\mathrm{Pu}$ concentrations through applications of the $\mathrm{Pu} / \mathrm{Am}$ ratio, so this variability did not affect the data of Figs 2, 3, 4, 5, 6, and 7.) It is useful to examine the distributions of $\mathrm{Pu} / \mathrm{Am}$ because it varies with the original, contaminating event. Fig 8 shows that when multiple weapons tests caused the event we are likely to find a $\log$ normal $\mathrm{Pu} / \mathrm{Am}$ distribution. But when only a single weapons test occurred, a normal $\mathrm{Pu} / \mathrm{Am}$ distribution obtains - (see Fig 9).

In the case of the North plume, Lots 18 and 19, where several weapons tests contributed to the contamination, there were nevertheless log normal distributions of the concentration $\mathrm{C}$ of $\mathrm{Pu}$, concentration $\mathrm{M}$ of TSP, and aerosol activity, $E_{f} \mathrm{~A}$.

Figs 10, 11, and 12 show the distribution of measurements of C, M, and $E_{f} \mathrm{~A}$ in suspended aerosols north of the uncleaned north border of the north plume (Lot 18), where recontamination of undisturbed soil occurred. 


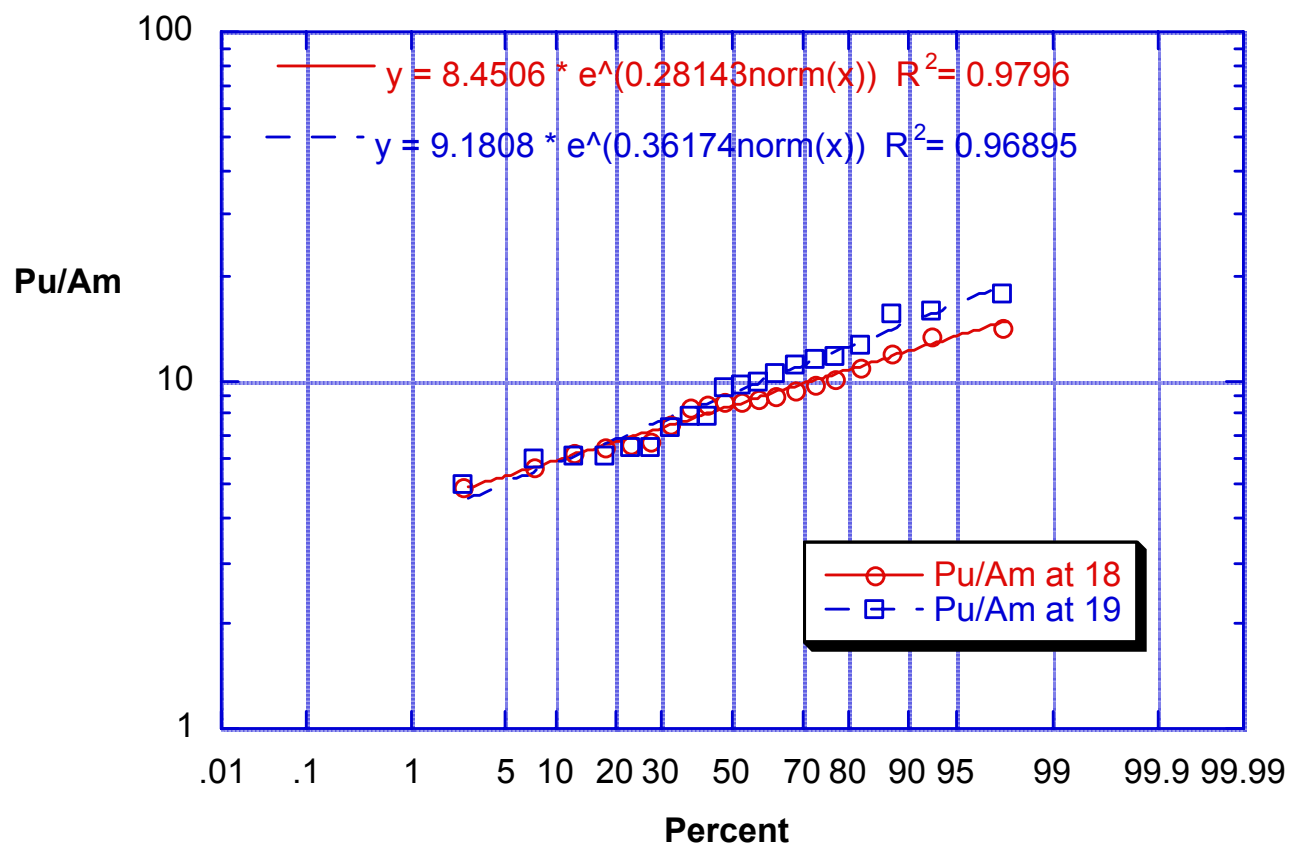

Fig 8. Ratio ${ }^{239,240} \mathrm{Pu} /{ }^{241} \mathrm{Am}$ North plume, Lots 18 \& 19

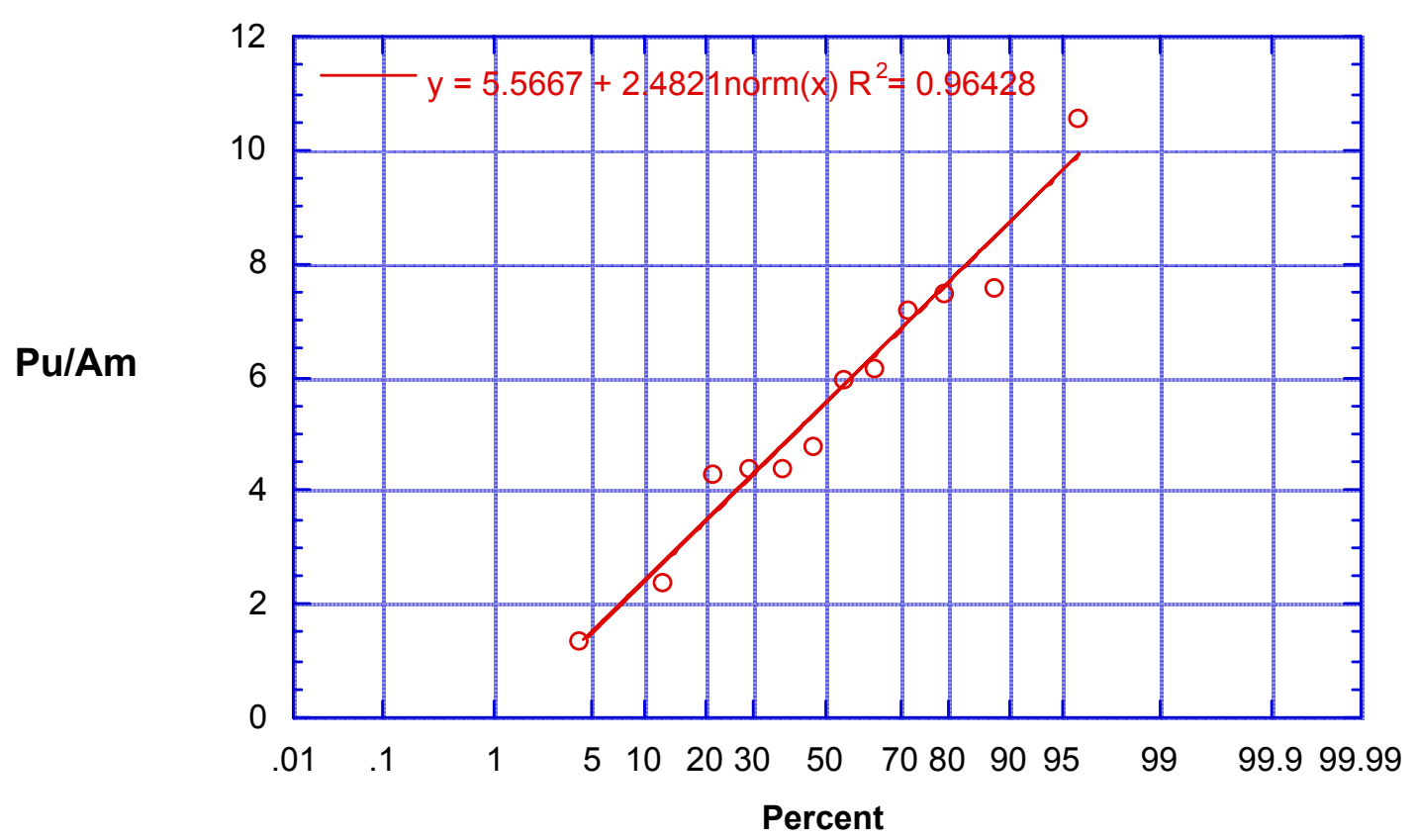

Fig 9. Ratio ${ }^{239,240} \mathrm{Pu} /{ }^{241} \mathrm{Am}$ in Air, FW site, Taranaki 


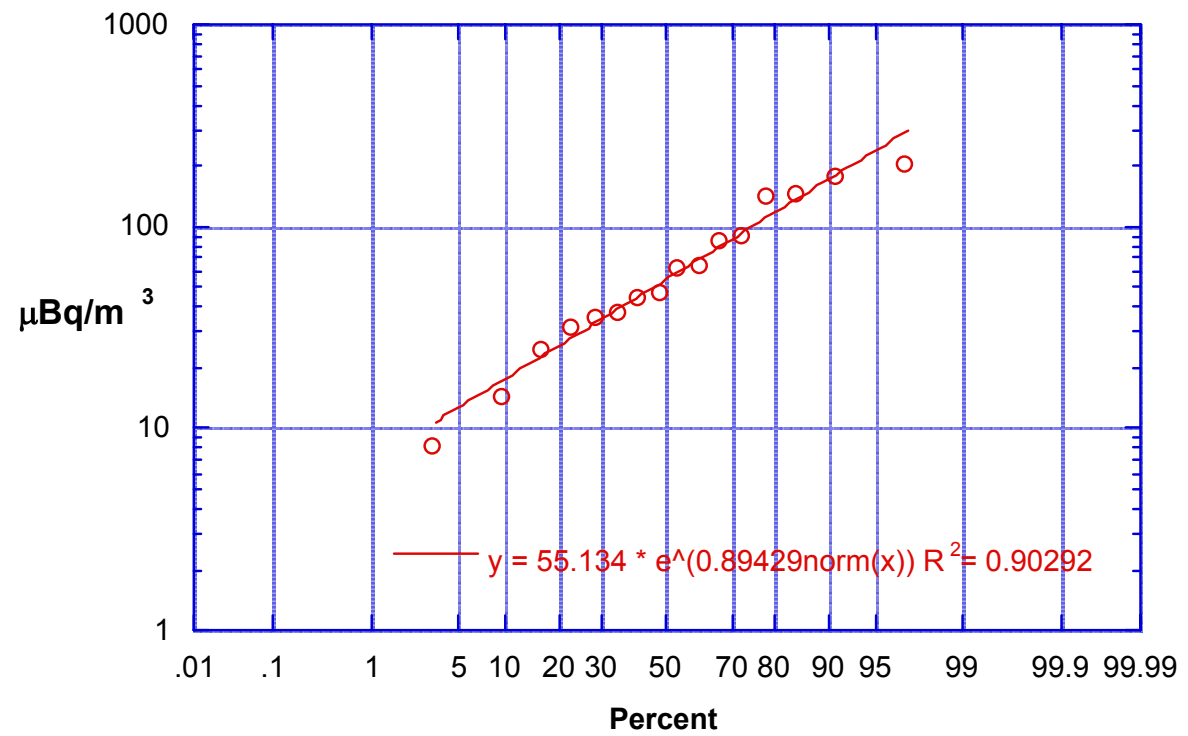

Fig 10. Concentrations of $\mathrm{Pu}$ in air, North plume Lot 18 , Taranaki

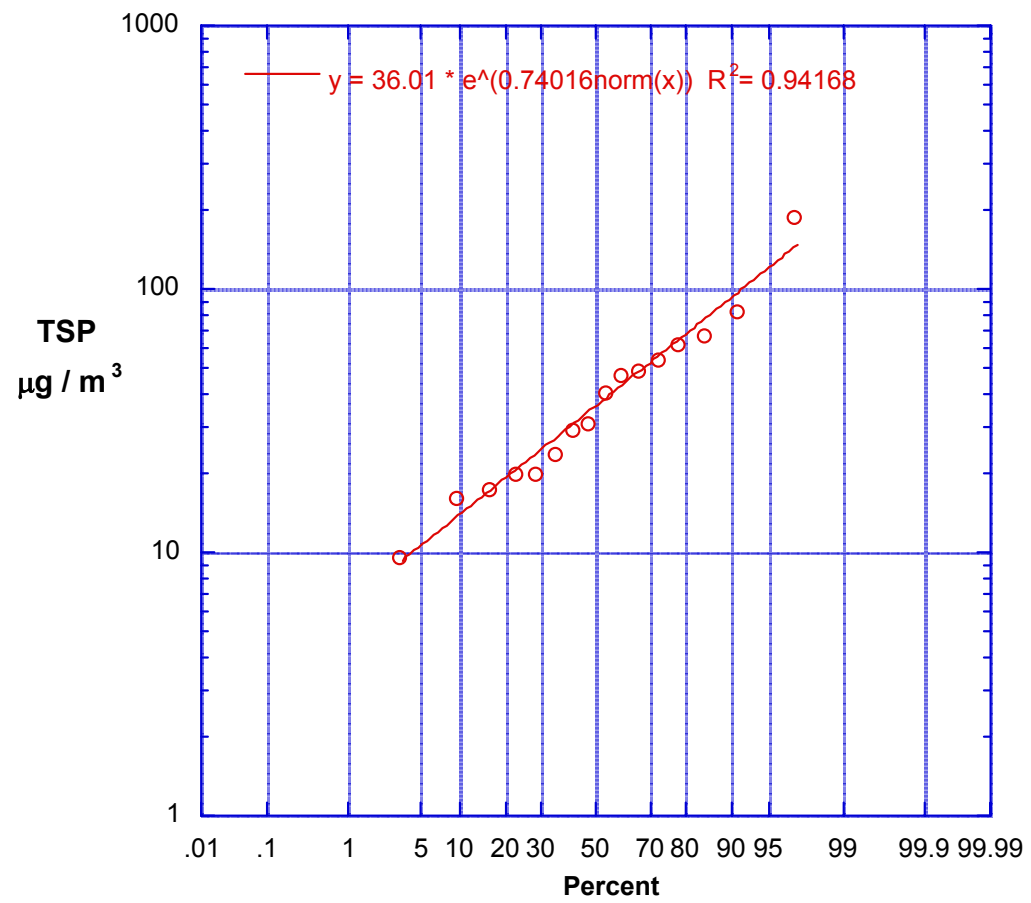

Fig 11. Concentrations of TSP in air, North plume Lot 18, Taranaki 


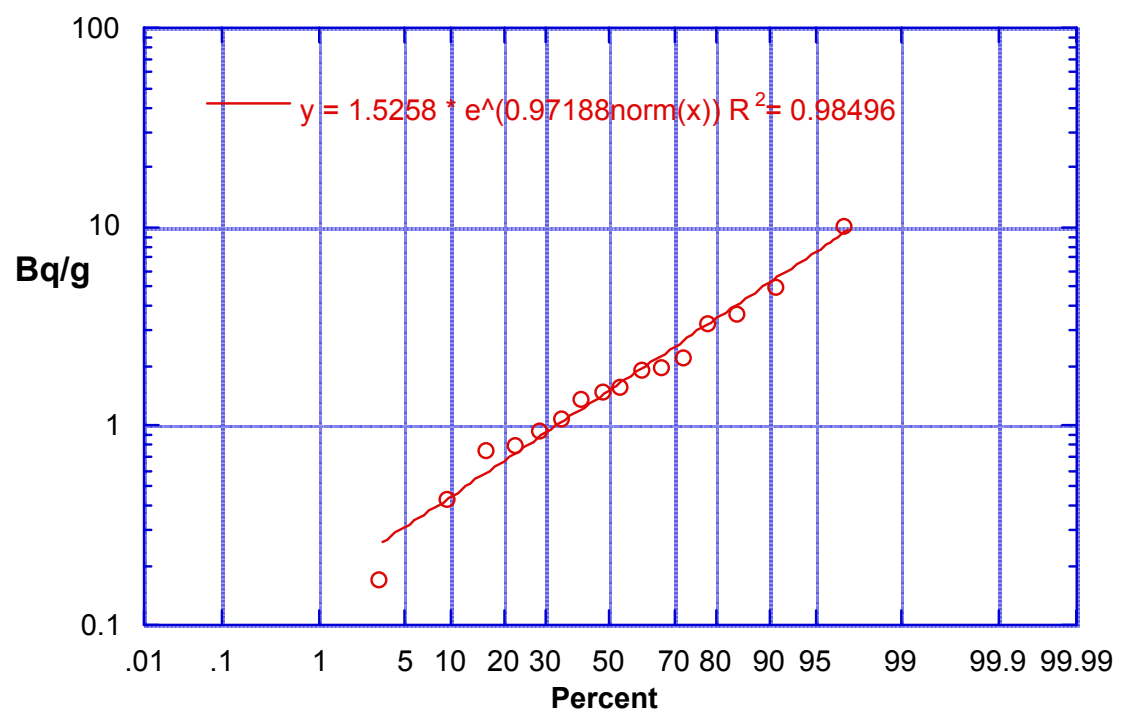

Fig 12. Pu activity, North plume Lot 18 , Taranaki

The same kind of log normal behavior occurred in the cleaned Taranaki North plume, Lot 19. Results for $\mathrm{C}$ and $\mathrm{M}$ at this site are shown in Figs 13 and 14, while a notable exception is the distribution of air activity, $E_{f} \mathrm{~A}$, shown in Fig 15.

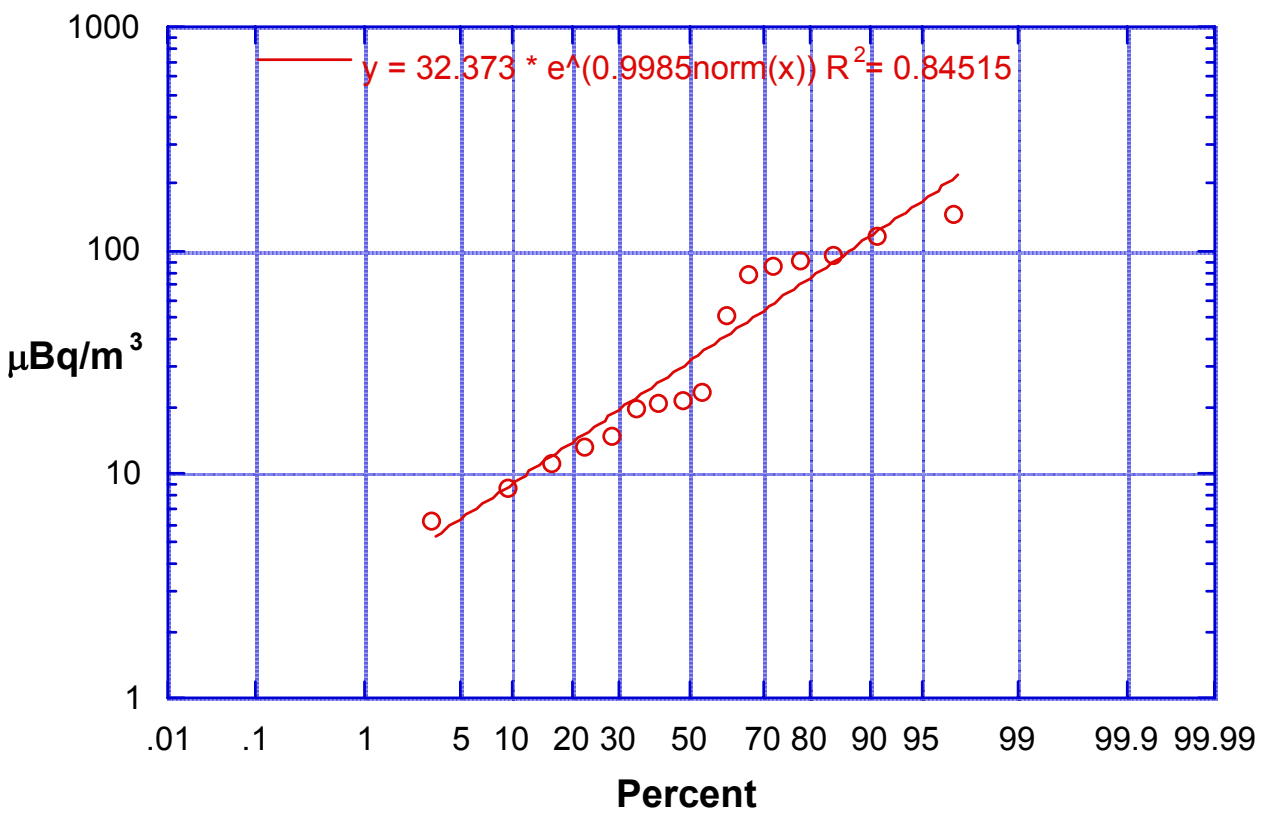

Fig 13. Pu concentration in air, North plume Lot 19, Taranaki 


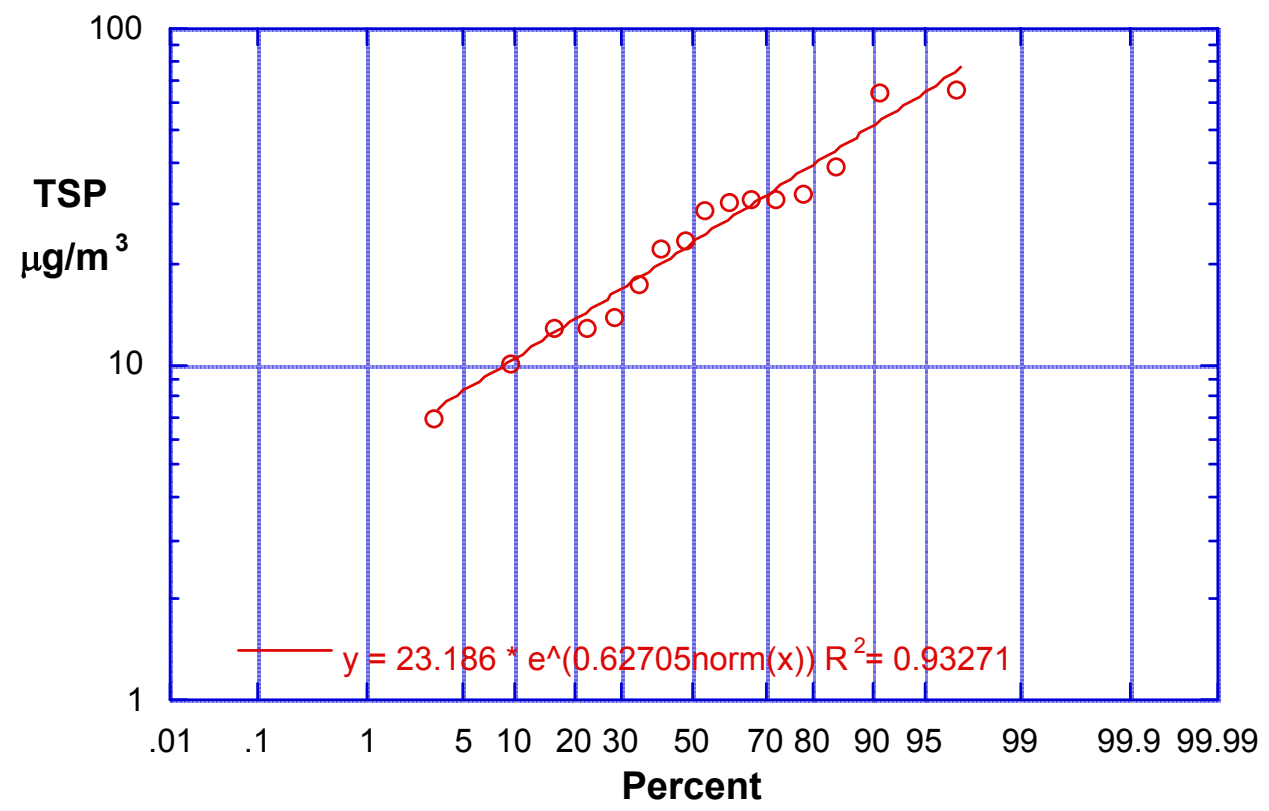

Fig 14. Concentration of TSP, North plume Lot 19, Taranaki

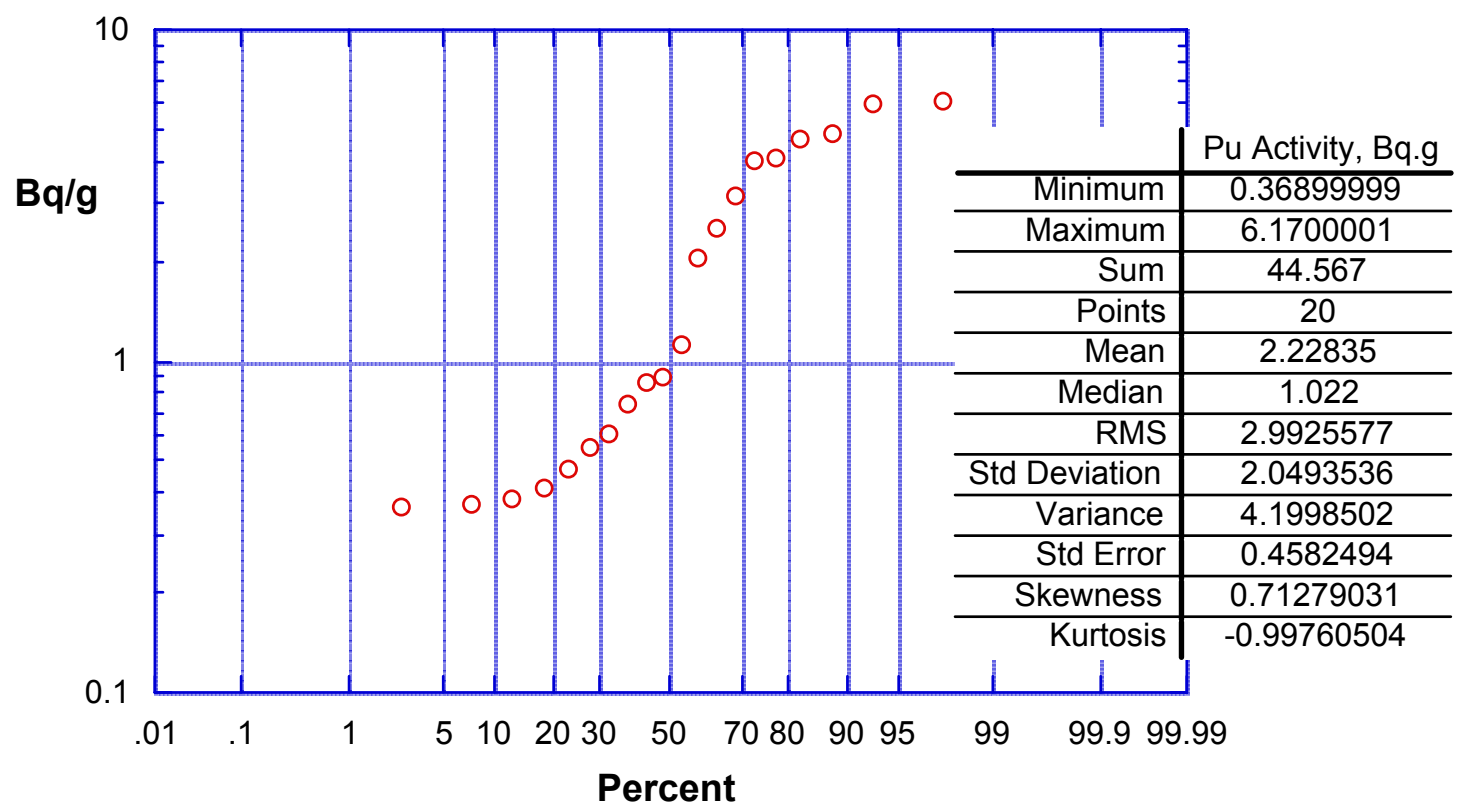

Fig 15. Pu Activity in Aerosols, North plume Lot 19, Taranaki (an unusual distribution).

A possible explanation of the strange distribution of $\mathrm{Pu}$ activity observed in the particulate aerosols in Lot 19 is that after the surface cleaning the locations of deposition patterns from the intermingled weapons tests became heterogeneous. If so, we observed contamination from 
different weapons tests on separate samples and hence we have observed a confounded, composite distribution.

The data collected at TM-100 in October 1997 is somewhat at odds with what we expected to find. We observed much lower $\mathrm{Pu} / \mathrm{Am}$ ratios than expected (Table 2) and much lower resuspension factors $S_{f}$ than found at any of the Taranaki sites (Table 3). This difference was not due to sampling errors, as low values showed up in many observations of both $\mathrm{C}, \mathrm{Pu}$ concentrations in air (Fig 16, where the deposition was about $4 \mathrm{kBq} / \mathrm{m}^{2}$ ) and the $\mathrm{Pu} / \mathrm{Am}$ ratios (Fig 17) for TM-100, Lot 12.

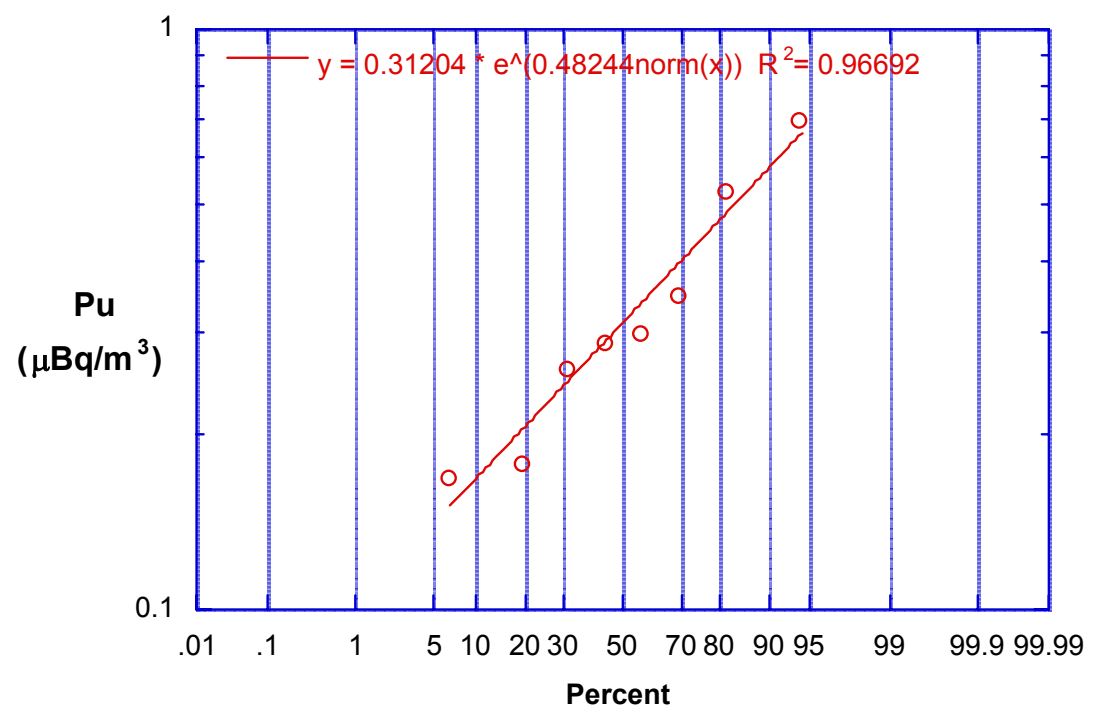

Fig 16. Pu concentration in air, TM-100 Lot 12, undisturbed control.

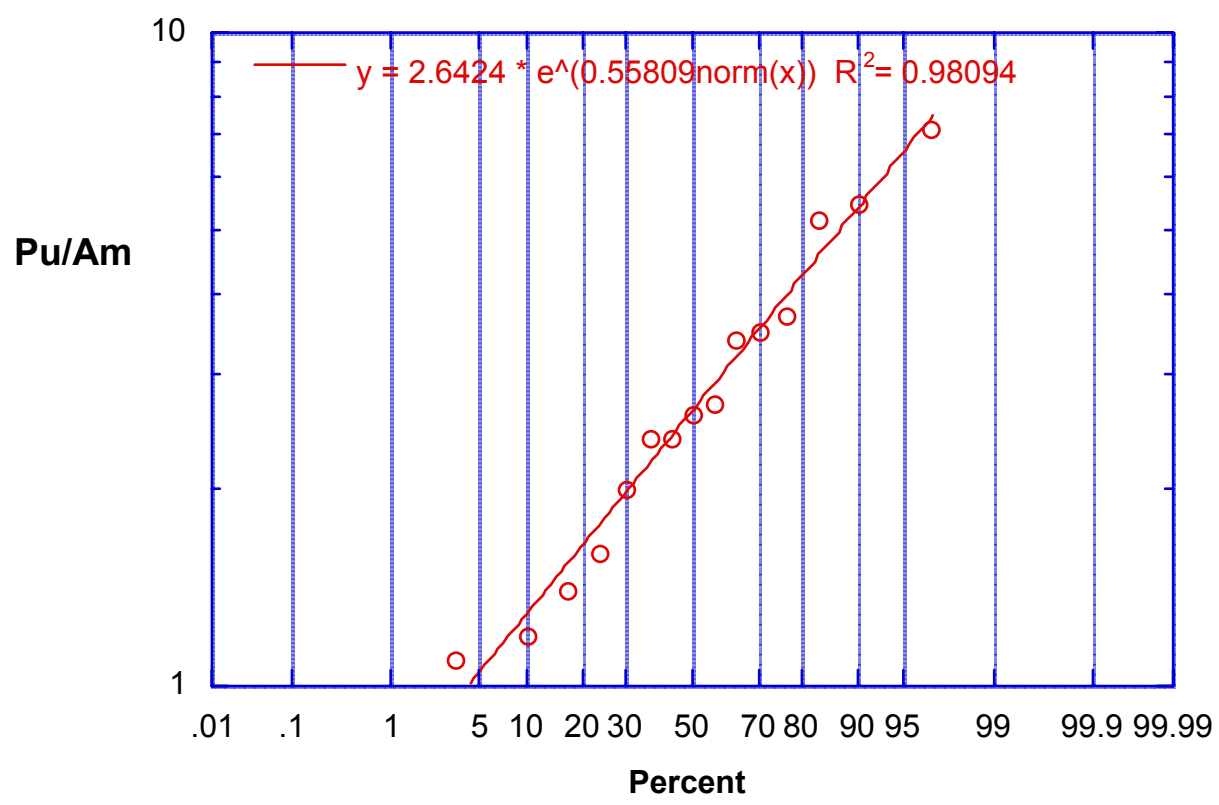

Fig 17. Ratio ${ }^{239,240} \mathrm{Pu} /{ }^{241} \mathrm{Am}, \mathrm{TM}-100$ Lot 12. 
4. Loss of Pu through continued resuspension due to wind erosion.

Since the variability has been well documented, one remaining question was the predictability of the surface stability. The estimation of resuspension rates $\mathrm{S}_{\mathrm{f}}$ depended upon the vertical gradient of $\mathrm{C}$ and $\mathrm{M}$ measured using the vertical array system (VAS) described under Methods Part 2. The Eqn 6 vertical gradient parameter, p, observations are summarized in Table 5. The values are similar to those observed elsewhere.

TABLE 5. VALUES OF NON-DIMENSIONAL VERTICAL GRADIENT, $p$

\begin{tabular}{cccc}
\hline Site & $\begin{array}{c}\text { Observed } \\
\mathrm{p}(\mathrm{TSP})\end{array}$ & $\begin{array}{c}\text { Observed } \\
\mathrm{p}(\mathrm{Pu})\end{array}$ & Comments* \\
\hline Taranaki West & -0.23 & -0.54 & Undisturbed control site \\
Taranaki North, \#19 & -0.11 & -0.28 & Cleaned site \\
Taranaki North, \#18 & -0.18 & -0.39 & Uncleaned, recontaminated \\
Taranaki Northeast & -0.28 & -0.40 & Cleaned site (during storm) \\
TM-100 & -0.20 & -0.58 & Undisturbed control site \\
\hline
\end{tabular}

*Values are negative indicating a decrease in concentration with height, and a loss from the surface. The average ratio of $\mathrm{p}(\mathrm{Pu}) / \mathrm{p}(T S P)=2.3$ with standard deviation 0.6

The mean vertical profiles of $\mathrm{C}$ and $\mathrm{M}$ are shown in Figs 18 and 19 with the slopes fitted by least squares regression given in the first row of Table 5.

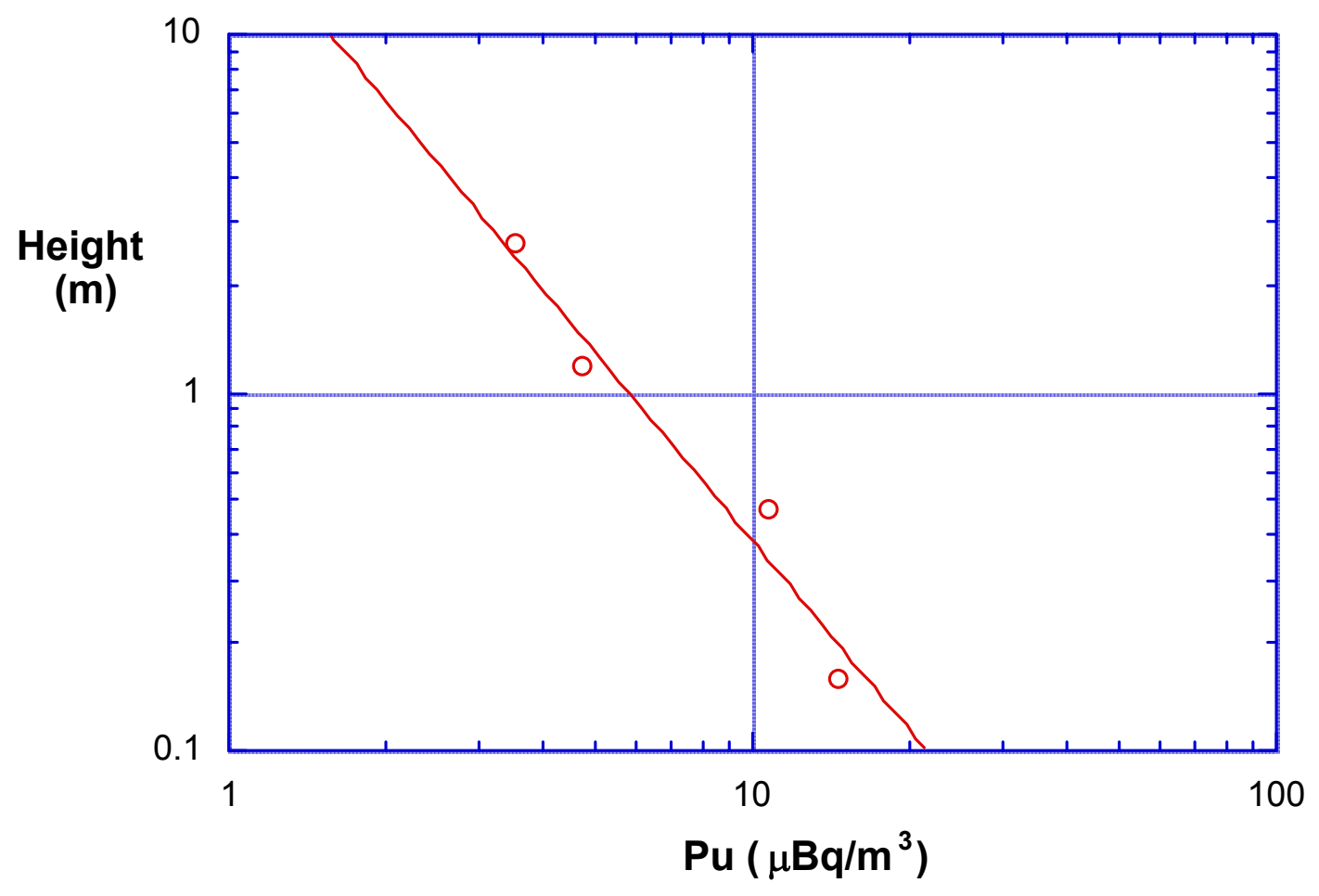

Fig 18. Vertical gradient of Pu observed at Taranki West, FW site. 
The vertical profiles of $\mathrm{C}$ and $\mathrm{M}$ can be seen to be slightly different. This same characteristic is shown during the dust storm of November, 1996, at Taranaki Northeast, in Figs 20 and 21. The ratio of the slopes is on average about 2.3 (see Table 5).

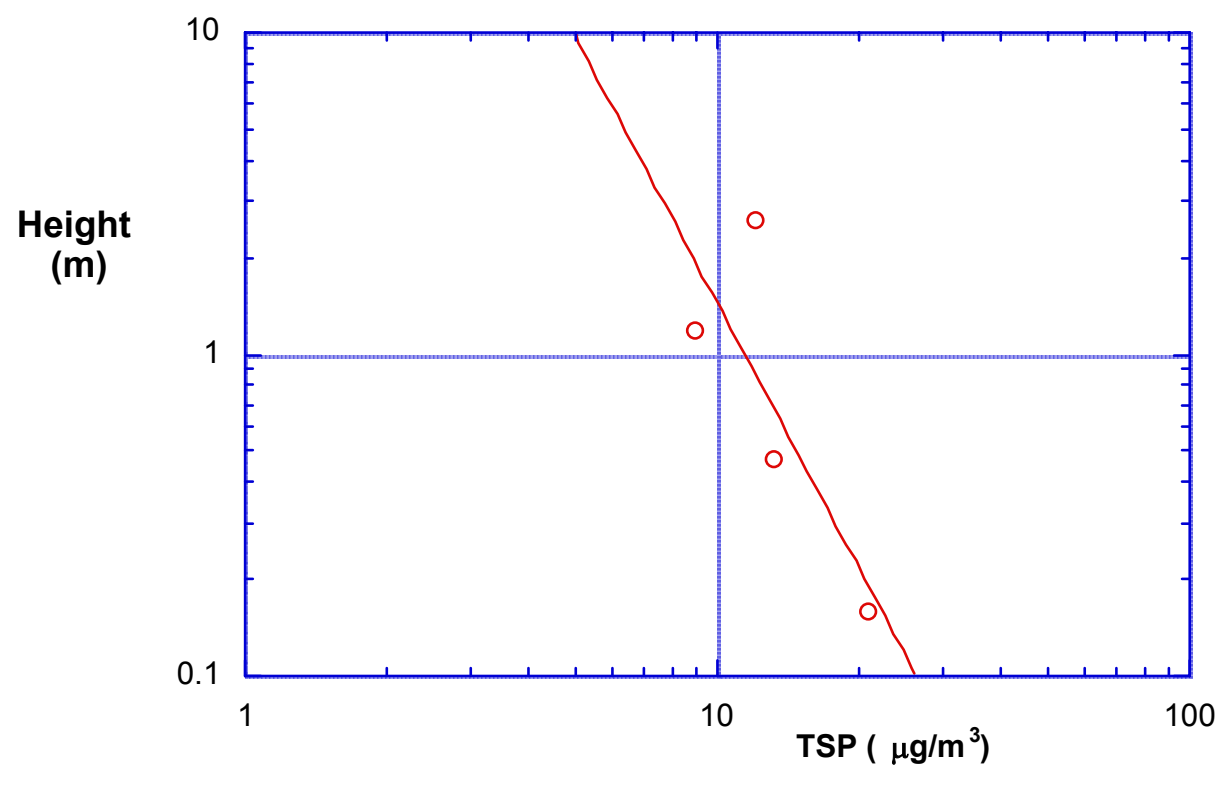

Fig 19. TSP profile at Taranaki West, FW site.

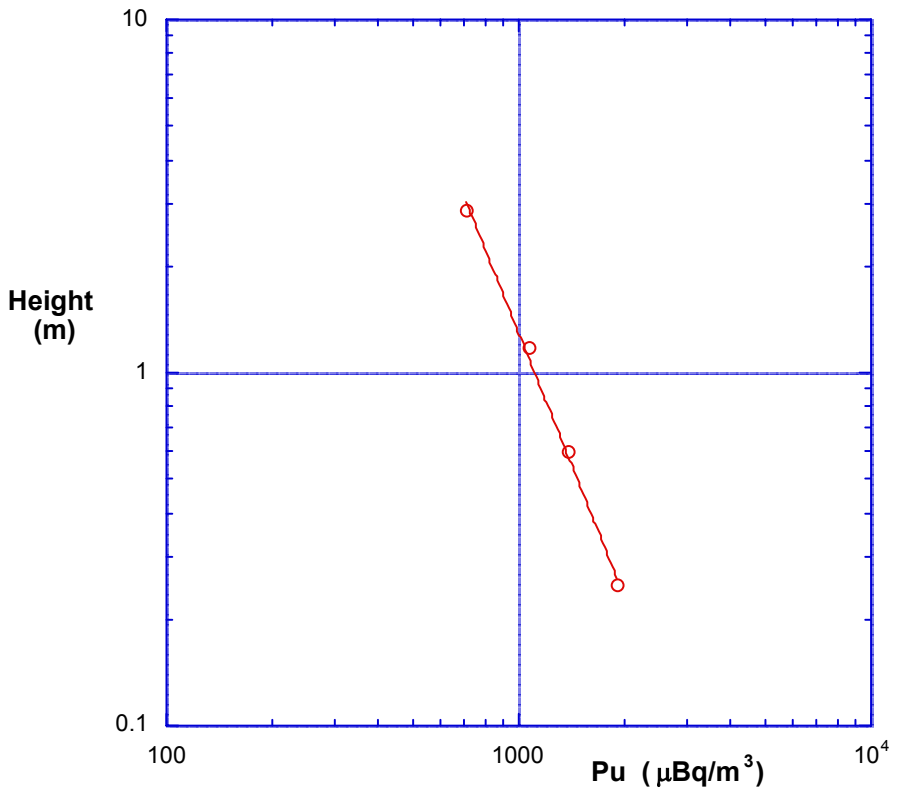

Fig 20. Vertical gradient of Pu at Taranaki Northeast during storm. 


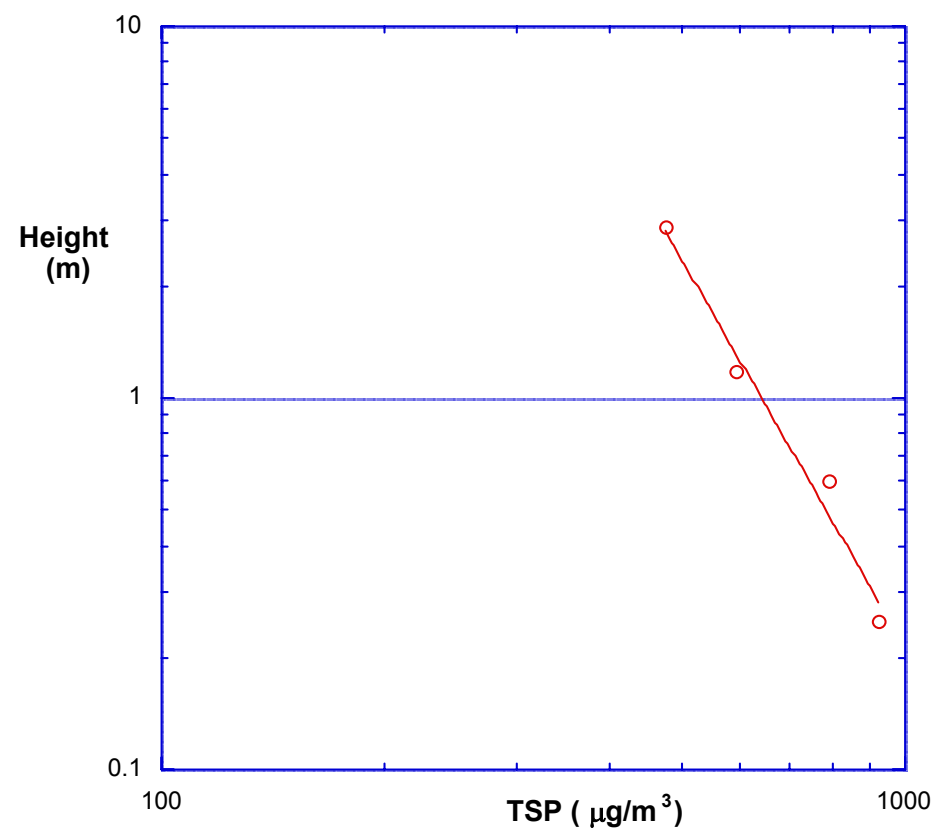

Fig 21. Vertical gradient of TSP at Taranaki Northeast during storm.

We have observed at Tonopah, Nevada, that the profiles are often shifted toward higher concentrations without a change in slope. Hence, p-values can be similar in stormy and nonstormy conditions. This is shown in Table 5 where p-values in row 4 are not much different than p-values in row 1. Likewise TM-100 with very low resuspension rates has similar pvalues as the Taranaki sites; (see Fig 22, which is plotted with a graphical rotation to show both $\mathrm{C}$ and $\mathrm{M}$ ).

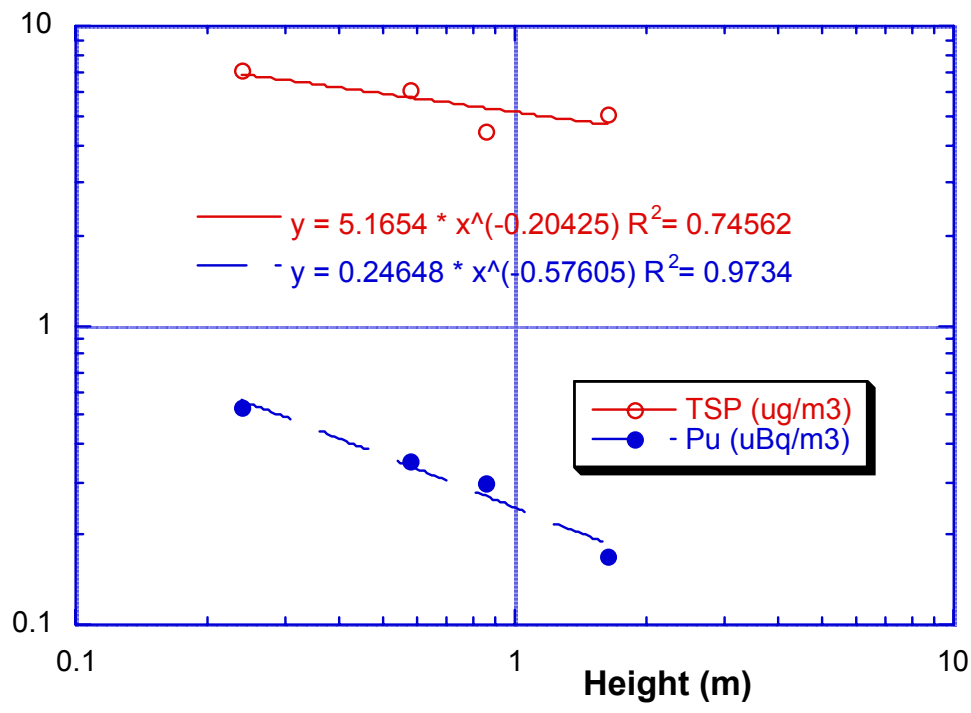

Fig 22. Vertical profiles of Pu and TSP at TM-100 Lot 12 
Wind, p-values, and resuspension factors enter into the determination of the stability of Maralinga sites. The key parameters as defined by Eqns 3-7 and then observed at Maralinga are shown in Table 6. We calculated a resuspension rate for Taranaki control site, a cleaned site, and the TM-100 uncleaned site. The calculations show that if the resuspension rate remained constant, it would take a few thousand years to remove it by wind erosion in the worst case, which is the cleaned plot. On the other hand the resuspension rate at Taranaki North would be expected to eventually decrease to probably something like the Taranaki West undisturbed site. The revegetation rate will assist this if rehabilitation is successful.

\section{TABLE 6. CALCULATED RESUSPENSION RATES}

\begin{tabular}{|c|c|c|c|c|c|c|}
\hline Site & $\begin{array}{l}\text { Wind } \\
\text { speed } \\
\text { at } 2 \mathrm{~m} \\
(\mathrm{~m} / \mathrm{s})\end{array}$ & $\begin{array}{c}\text { Diffusivit } \\
\mathrm{y} \\
\mathrm{K} \\
\left(\mathrm{m}^{2} / \mathrm{s}\right)\end{array}$ & $\begin{array}{l}\text { Vertical } \\
\text { Gradient } \\
\mathrm{p}(\mathrm{Pu})\end{array}$ & $\begin{array}{l}\text { Resuspension } \\
\text { factor } \mathrm{S}_{\mathrm{f}} \\
\left(\mathrm{m}^{-1}\right)\end{array}$ & $\begin{array}{c}\text { Resuspension } \\
\text { rate } \\
\left(\sec ^{-1}\right)^{*}\end{array}$ & $\begin{array}{l}\text { Time to lose } \\
\text { one-half } \\
(y r s)^{* *}\end{array}$ \\
\hline $\begin{array}{l}\text { Taranaki West, } \\
\text { undisturbed }\end{array}$ & 4.3 & 0.205 & -.54 & $3 \times 10^{-10}$ & $2.77 \times 10^{-11}$ & 7900 \\
\hline $\begin{array}{l}\text { Taranaki North, \#19 } \\
\text { cleaned lot }\end{array}$ & 3.5 & 0.106 & -.28 & $4 \times 10^{-9}$ & $1.0 \times 10^{-10}$ & 2200 \\
\hline $\begin{array}{l}\text { TM-100, } \\
\text { uncleaned }\end{array}$ & 3.6 & 0.168 & -.58 & $3 \times 10^{-11}$ & $2.3 \times 10^{-12}$ & 95500 \\
\hline
\end{tabular}

* Resuspension rate $=\mathrm{K}(\mathrm{p} / \mathrm{z}) \mathrm{S}_{\mathrm{f}}$ where height of Pu measurement $\mathrm{z}=1.2 \mathrm{~m}$

**For the sake of visualization, the resuspension rate is converted to time for resuspension to remove one-half of the $\mathrm{Pu}$ in the soil providing that the rate stays constant over time.

The diffusivity, $\mathrm{K}$, would be expected to decrease on a clean, smooth plot due to the removal of surface roughness, $z_{0}$. This was observed at Maralinga-(see Fig 23). The effect may be temporary, however, because restoration with vegetation and water erosion will combine to make the cleaned surface rough over time.

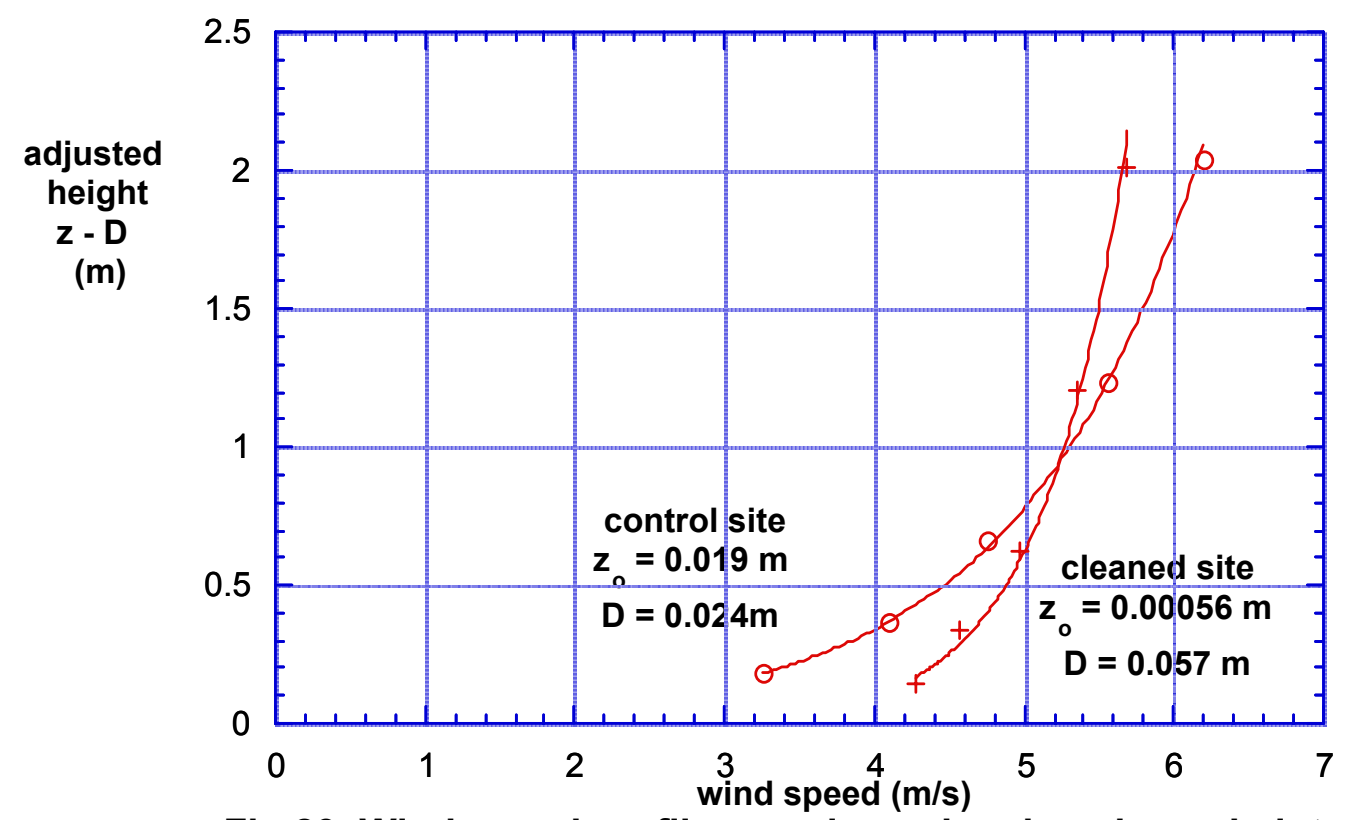

Fig 23. Wind speed profiles on cleaned and uncleaned plots. 


\section{EFFECTIVENESS OF REHABILITATION}

After the soil surfaces had been cleaned and stabilized and following a few years of natural weathering, the rehabilitation effect was noticeable in the reduced $\mathrm{Pu}$ concentrations in air. In April-May 2000, the air flowing over the former deposition plumes at Taranaki picked up $\mathrm{Pu}$ concentrations near $0.1 \mu \mathrm{Bq} / \mathrm{m}^{3}$, and at TM-100 and Wewak, the $\mathrm{Pu}$ concentrations in air were on the order of $0.01 \mu \mathrm{Bq} / \mathrm{m}^{3}$. These compare to a value of $0.006 \mu \mathrm{Bq} / \mathrm{m}^{3}$ at Maralinga Village during the same period. See Table 7. (There are very few locations in the world monitoring airborne $\mathrm{Pu}$, but we obtained a value of $0.0004 \mu \mathrm{Bq} / \mathrm{m}^{3}$ for a station in Melbourne, and a value of $0.002 \mu \mathrm{Bq} / \mathrm{m}^{3}$ for a representative northern hemisphere site in California.)

Rehabilitation has reduced $\mathrm{Pu}$ concentrations in air, $\mathrm{C}$, by more than a factor of 100 at Taranaki by comparison to values in Table 4. Measurements by ARPANSA in the vicinity of the air samplers in April-May 2000 showed deposition of ${ }^{241} \mathrm{Am}$, D, approximately 0.3 $\mathrm{kBq} / \mathrm{m}^{2}$ and with the aid of a $\mathrm{Pu} / \mathrm{Am}$ ratio of 10 from Table 2, and $\mathrm{Eq} 1$, we calculated an approximate resuspension factor $S_{\mathrm{f}}$ of $3 \times 10^{-11} \mathrm{~m}^{-1}$. This shows that the resuspension factor has returned to the undisturbed state below that shown in Table 6 for Taranaki during cleanup.

TABLE 7. PU CONCENTRATIONS IN AIR AFTER MARALINGA REHABILITATION

\begin{tabular}{cccc}
\hline Site & $\begin{array}{c}\text { Sampled air } \\
\text { Volume } \\
\left(\mathrm{m}^{3}\right)\end{array}$ & $\begin{array}{c}\text { Observed } \\
\text { Pu } \\
\left(\mu \mathrm{Bq} / \mathrm{m}^{3}\right)\end{array}$ & $\begin{array}{c}\text { Dates } \\
\text { In 2000 }\end{array}$ \\
\hline Taranaki FNE, Northeast & 102000 & 0.050 & April 27-29 \\
Taranaki FN, North & 149000 & 0.122 & May 2-5 \\
April 30-May 2 \\
Taranaki FNW, Northwest & 123000 & 0.126 & May 5-7 \\
TM-100, Northeast & 110000 & 0.012 & May 7-9 \\
Wewak & 101000 & 0.011 & \\
CONTROLS & & & April 27-May 8 \\
Maralinga Village & 112000 & 0.006 & Annual Median \\
California Rural Site* & --- & 0.002 & March 31-May 15 \\
ARPANSA, Melbourne** & 316000 & 0.0004 & \\
\hline
\end{tabular}

*Annual Site Environmental Report, Lawrence Livermore National Laboratory.

**Uncertainty of Maralinga samples is less than 2\% and uncertainty of Melbourne samples is $60 \%$ by the method of accelerator mass spectroscopy.

\section{CONCLUSIONS}

There are indications that in the long run the concentrations of $\mathrm{Pu}$ in the air will become equivalent to world-wide background; values near $0.1 \mu \mathrm{Bq} / \mathrm{m}^{3}$ were already evident at Taranaki in 2000. The resuspension factors in 1996-1997 and 2000 were low and within an order of magnitude, or below, the typical values found worldwide, $10^{-10} \mathrm{~m}^{-1}$. Surface sealing by rain, and revegetation has continued to stabilize the soil. 
We have observed the important variables and the uncertainty: size of the suspended aerosols, $\mathrm{Pu}$ concentrations in air, TSP concentrations in air, $\mathrm{Pu}$ activity on aerosols, resuspension factors, and wind effects. We have calculated potential resuspension rates. There apparently is nothing out of the ordinary with respect to these values in contributing to potential human exposure. Our measurements for the most part agree with those made by ARPANSA, and show that the dose assessment considerations were very conservative and protective of the public from a radiological perspective. Assumptions made about enhancements and dusty environments for dose assessment purposes are likely to be bounding case assumptions and even more extra protective of the Aboriginal people.

\section{REFERENCES}

Anspaugh, L. R., J. H. Shinn, P. L. Phelps, and N. C. Kennedy (1975), "Resuspension and redistribution of plutonium in soils," Health Physics 29:571-582.

Bertoldo, N. A. (1998), Resuspension of plutonium contamination at the Taranaki Nuclear Test Site, M.S. Thesis, Radiological Health Physics, San Jose State University, 108pp.

Burns, P. A., M. B. Cooper, K. H. Lokan, M. J. Wilks, and G. A. Williams (1995), "Characteristics of Plutonium and Americium Contamination at the Former U.K. Atomic Weapons Test Ranges at Maralinga and Emu,” Appl. Radiat. Isot. 46(11):1099-1107

Burns, P. A., M. B. Cooper, P. N. Johnston, L. J. Martin, and G. A. Williams (1994), "Determination of the Ratios of ${ }^{239} \mathrm{Pu}$ and ${ }^{240} \mathrm{Pu}$ to ${ }^{241} \mathrm{Am}$ for Nuclear Weapons Test Sites in Australia," Health Physics 67(3):226-232.

Gilbert, R. O., D. W. Engel, D. D. Smith, J. H. Shinn, L. R. Anspaugh, and G. R. Eisele (1988a), "Transfer of Aged Pu to Cattle Grazing on a Contaminated Environment," Health Physics 54(3):323-335.

Gilbert, R. O., J. H. Shinn, E. H. Essington, T. Tamura, E. M. Romney, K. S. Moor, and T. P. O'Farrell (1988b), "Radionuclide Transport from Soil to Air, Native Vegetation, Kangaroo Rats and Grazing Cattle on the Nevada Test Site," Health Physics 55(6):869-867.

Johnston, P. N., G. A. Williams, Peter A. Burns, and Malcolm B. Cooper (1993), "Plutonium Resuspension and Airborne Dust Loadings in the Desert Environment of Maralinga, South Australia," J. Environ. Radioactivity 20:117-131.

Johnston, P. N., K. H. Lokan, and G. A. Williams (1992), "Inhalation Doses for Aboriginal People Reoccupying Former Nuclear Weapons Testing Ranges in South Australia," Health Physics, 63(6):631-640.

Kehl, S. R., M. E. Mount, and W. L. Robison (1995), The Northern Marshall Islands Radiological Survey: A Quality Control Program for Radiochemical and Gamma Spectroscopy Analysis, Technical Report UCRL-ID-120429, Lawrence Livermore National Laboratory.

McAninch, J. E., T. F. Hamilton, et al (1999), Plutonium Measurements by Accelerator Mass Spectrometry at LLNL, Technical Report UCRL-JC-136204, Lawrence Livermore National 
Laboratory. Presentation to $8^{\text {th }}$ International Conference on Accelerator Mass Spectrometry, Vienna, Austria, Sept 6-10, 1999.

NCRP (1999), Recommended Screening Limits for Contaminated Surface Soil and Review of Factors Relevant to Site-Specific Studies, NCRP Report No. 129, National Council on Radiation Protection and Measurements, Bethesda, MD, USA.

Shinn, J. H. (1992), "Enhancement Factors for Resuspended Aerosol Radioactivity: Effects of Topsoil Disturbance," Proceedings of the Fifth International Precipitation Scavenging and Atmosphere-Surface Exchange, Richland Washington, 15-19 July 1991,Vol 3:1183-1193, Eds. S. E. Schwartz and W. G. N. Slinn, Hemisphere Publishing Corp.

Shinn, J. H., D. N. Homan, and W. L. Robison (1997), "Resuspension Studies in the Marshall Islands," Health Physics, 73(1):248-257.

Shinn, J. H., E. H. Essington, F. L. Miller Jr., T. P. O'Farrell, J. A. Orcutt, E. M. Romney, J. W. Shugart, and E. R. Sorom (1989), "Results of a Cleanup and Treatment Test at the Nevada Test Site: Evaluation of Vacuum Removal of Pu-Contaminated Soil," Health Physics, 57(5):771-779.

Williams, G. A. (1993), Dose Assessment Studies at Former Nuclear Weapons Test Sites in Australia, International Atomic Energy Agency, IAEA-TECDOC-755:33-49.

Wong, K. M, T. A. Jokela, and V. E. Noshkin (1995), Radiochemical Procedures for Analysis of Pu, Am, Cs, and Sr in Water, Soil, Sediments, and Biota Samples, Technical Report UCRL1D-116497, Lawrence Livermore National Laboratory. 


\section{APPENDIX 1.}

Maralinga Map and Cleanup Lot Maps. Taken from Maralinga Rehabilitation Technical Advisory Committee, Rehabilitation of Former Nuclear Test Sites at Emu and Maralinga (Australia) 2003, Commonwealth of Australia, Department of Education, Science and Training, 403pp.

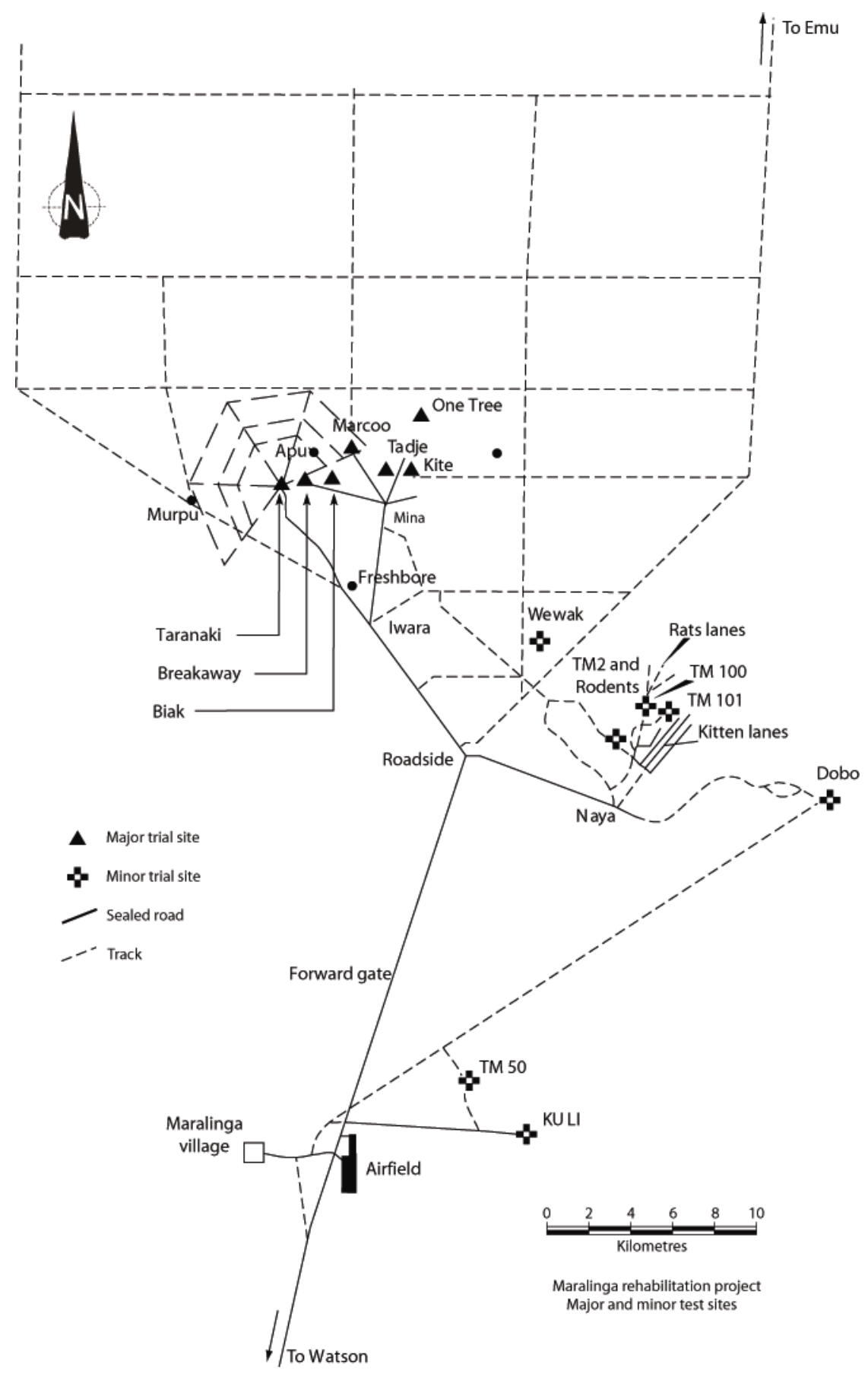

Map showing the locations of Taranaki, TM-100/101, Wewak and Maralinga Village. 


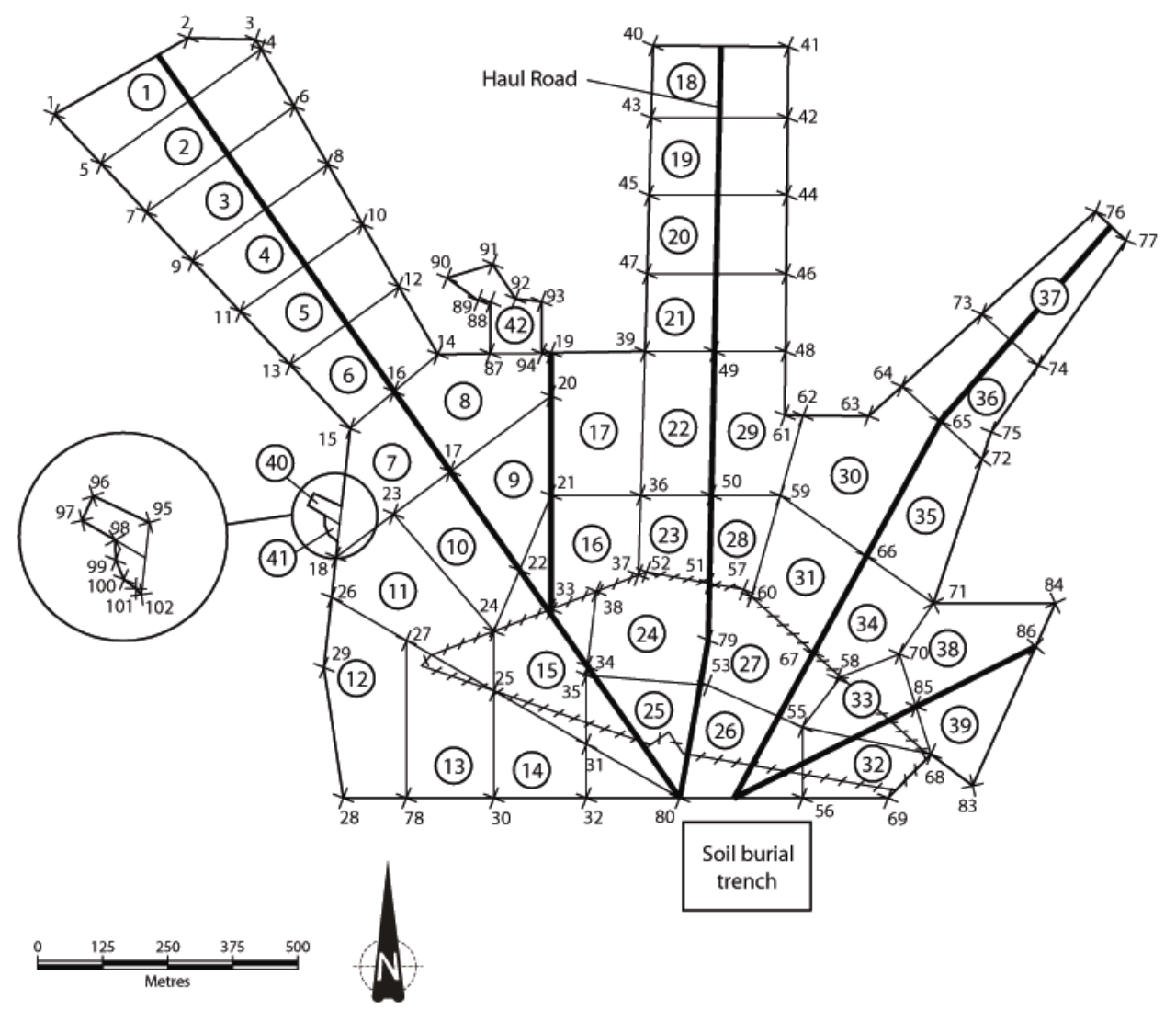

Taranaki cleanup lots.

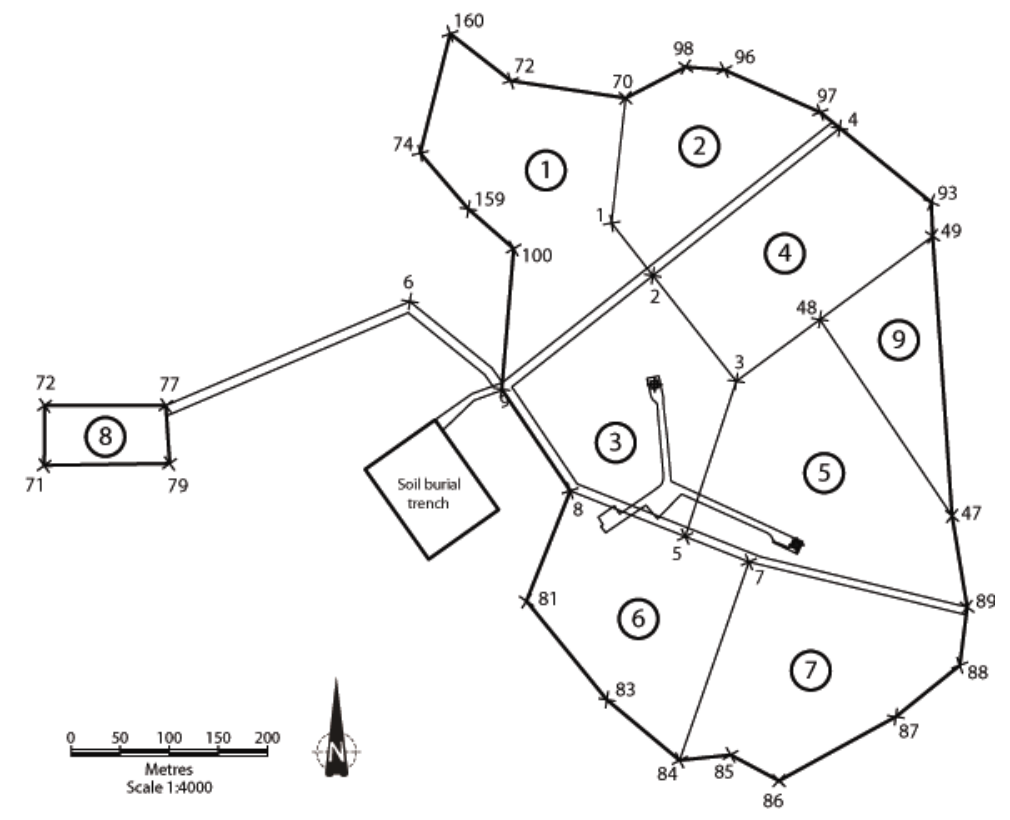

Wewak cleanup lots. 


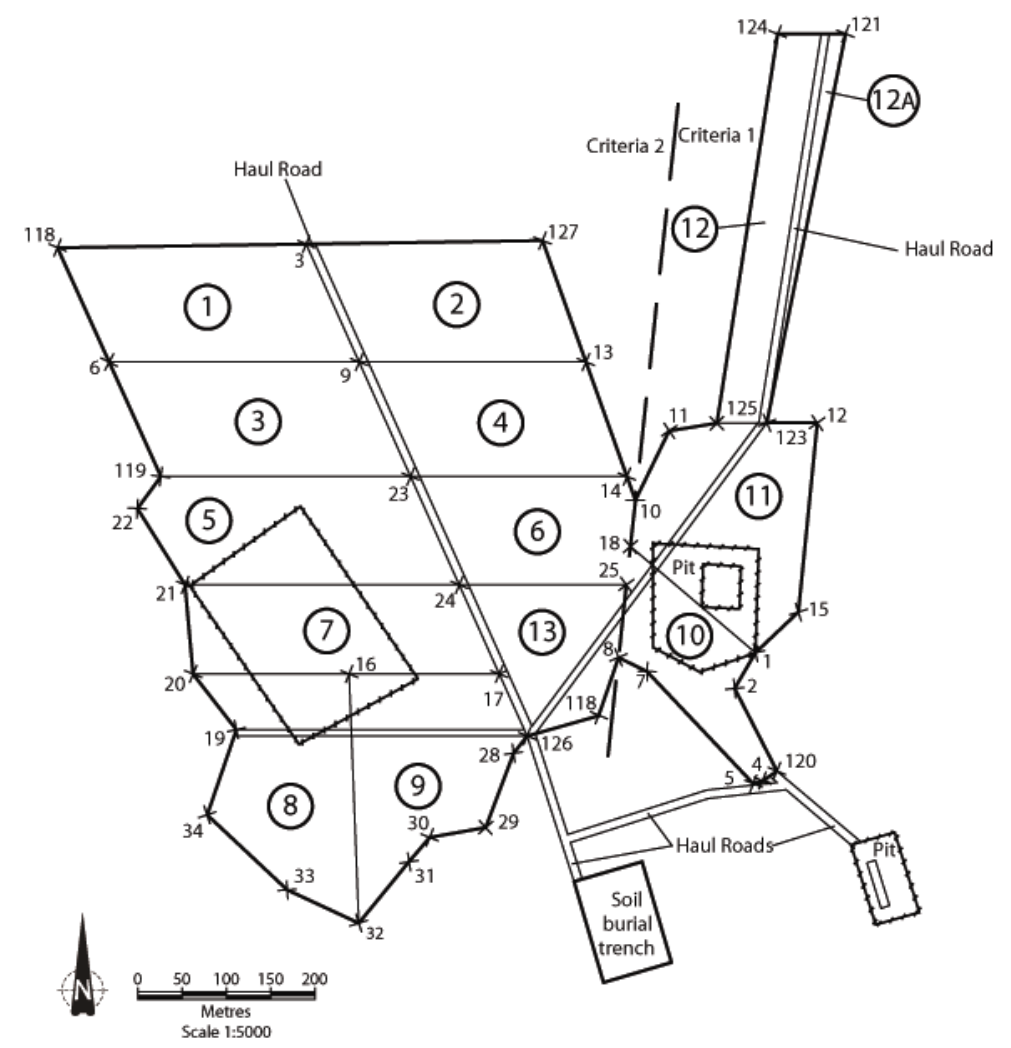

TM-100/101 cleanup lots. 


\section{APPENDIX 2.}

Investigations by Bertoldo, 1999, using data collected with the isokinetic particle counting system included an attempt to fit the complex, observed size distributions by the sum of three, $\log$ normal distributions. The width of each distribution by GSD, the \% area enclosed by the curve, and the mass median aerodynamic diameters (MMAD) of the distributions were calculated. These can be compared by wind speed during the same period in Table A. The data were collected during March 1997 in the Taranaki North plume, Lot 18 (undisturbed, recontaminated plot) and Lot 19 (cleaned plot).

It is difficult to draw major conclusions about the results except that it is clear that from time to time small contributions are made by minor modes of larger size particles, and these contributions tend to increase when the winds increase beyond $4 \mathrm{~m} / \mathrm{s}$. It is sufficient to recognize that the particle size distribution is dynamic, and it is probably the average size distribution that is more important for purposes of human dose assessment. The cascade impactor thus serves a useful purpose in collecting median aerodynamic diameter information of both the Pu aerosols and suspended mass averaged over time.

TABLE A. FITTED LOG NORMAL CURVES TO OBSERVED PARTICLE SIZE DISTRIBUTIONS, AFTER BERTOLDO, 1999

\begin{tabular}{ccccccccccc}
\hline $\begin{array}{c}\text { Wind } \\
\text { Speed } \\
(\mathrm{m} / \mathrm{s})\end{array}$ & $\begin{array}{c}\text { SITE } \\
\&\end{array}$ & $\begin{array}{c}\# 1 \\
\text { TRIAL }\end{array}$ & $\begin{array}{c}\# 1 \\
\text { GSD }\end{array}$ & $\begin{array}{c}\# 1 \\
\text { area }\end{array}$ & $\begin{array}{c}\text { MMAD } \\
\text { GSD }\end{array}$ & $\begin{array}{c}\# 2 \\
\% \\
\text { area }\end{array}$ & $\begin{array}{c}\# 2 \\
\text { MMAD }\end{array}$ & $\begin{array}{c}\# 3 \\
\text { GSD }\end{array}$ & $\begin{array}{c}\# 3 \\
\% \\
\text { area }\end{array}$ & $\begin{array}{c}\# 3 \\
\text { MMAD }\end{array}$ \\
\hline 1.73 & $18 / 4$ & 1.57 & 63 & 5.9 & 1.13 & 24 & 3.8 & 1.13 & 13 & 6.0 \\
2.78 & $18 / 5$ & 1.62 & 75 & 7.0 & 1.10 & 12 & 3.8 & 1.13 & 13 & 6.0 \\
3.52 & $18 / 6$ & 1.55 & 77 & 6.2 & 1.10 & 11 & 3.8 & 1.14 & 12 & 5.9 \\
3.52 & $18 / 7$ & 1.60 & 63 & 6.6 & 1.14 & 17 & 3.9 & 1.16 & 20 & 6.0 \\
4.39 & $18 / 8$ & 1.60 & 47 & 7.1 & 1.15 & 40 & 4.9 & 1.10 & 13 & 6.8 \\
4.35 & $18 / 9$ & 1.50 & 63 & 6.9 & 1.10 & 22 & 4.7 & 1.13 & 15 & 6.5 \\
& & & & & & & & & & \\
2.79 & $19 / 1$ & 1.55 & 69 & 6.6 & 1.12 & 18 & 4.2 & 1.14 & 13 & 6.0 \\
3.15 & $19 / 2$ & 1.57 & 74 & 6.7 & 1.10 & 18 & 4.1 & 1.12 & 8 & 5.9 \\
4.95 & $19 / 3$ & 1.57 & 65 & 6.8 & 1.13 & 20 & 4.0 & 1.14 & 15 & 6.0 \\
6.27 & $19 / 4$ & 1.62 & 40 & 7.2 & 1.23 & 33 & 4.8 & 1.15 & 27 & 6.2 \\
5.77 & $19 / 5$ & 1.46 & 40 & 5.9 & 1.30 & 57 & 6.5 & 1.02 & 3 & 8.9 \\
7.36 & $19 / 6$ & 1.56 & 36 & 7.9 & 1.47 & 59 & 8.9 & 1.02 & 5 & 8.9 \\
6.82 & $19 / 7$ & 1.55 & 88 & 10.3 & 1.03 & 3 & 7.1 & 1.03 & 9 & 8.8 \\
3.88 & $19 / 8$ & 1.52 & 55 & 6.4 & 1.15 & 33 & 4.6 & 1.11 & 12 & 6.5 \\
3.32 & $19 / 9$ & 1.52 & 60 & 6.4 & 1.13 & 27 & 4.5 & 1.13 & 13 & 6.8 \\
\hline
\end{tabular}

